\title{
LABOR ADJUSTMENT UNDER DIFFERENT INSTITUTIONAL STRUCTURES
}

\section{A Case Study of Germany and the United States}

Susan N. Houseman and Katharine G. Abraham

\section{INTRODUCTION}

Historically, U.S. employers have had the right to hire and fire at will. Adjustment to downturns has been accomplished largely through layoffs, rather than through reductions in average hours per worker or other alternatives to layoffs. In contrast, in Germany, as in most Western European countries, workers historically have enjoyed strong job rights, including the right to advance notice of layoff and the right to severance pay or to negotiations over compensation for layoff.

In recent years, laws and practices concerning collective dismissals have been under scrutiny both in the United States and in many Western European countries, including Germany. In the United States, the massive dislocations of the 1970's and early 1980's pushed many workers out of their jobs and led to growing pressure for legislated and collectively bargained job rights. Perhaps most significantly, a law requiring large employers to give 60 days' notice of plant closings and major layoffs was passed by the U.S. Congress in 1988. Ironically, at the same time that the United States was moving to strengthen workers' job security, many European countries were weakening their job security legislation in an effort to promote greater labor market flexibility. In Germany, the Employment Promotion Act of 1985 relaxed certain regulations on layoffs and permitted greater use of temporary and fixed-term contracts.

Central to the debate over workers' rights to job security on both sides of the Atlantic has been their presumed adverse impact on labor market flexibility. Critics have claimed that strong job rights prevent employers from adjusting to economic fluctuations and secular changes in demand. It also has been alleged that, by inhibiting layoffs during downturns, strong job security provisions reduce employers' willingness to hire during upturns and thereby contribute to high levels of unemployment. ${ }^{2}$ Some within the European Union have argued for a further weakening of European employment protection laws. ${ }^{3}$ 


\section{LABOR ADJUSTMENT UNDER DIFFERENT INSTITUTIONAL STRUCTURES}

Relatively little research, however, has been done on the effects of employment protection laws on labor market adjustment. Although German employment protection laws in and of themselves would be expected to slow the adjustment of employment to changes in demand, the magnitude of these effects is not known. Moreover, it does not necessarily follow that the costs of adjusting labor are higher in Germany than in the United States and consequently that German employers adjust less quickly to changing demand conditions. To determine the relative costs of adjusting labor in Germany and the United States, one must consider other relevant labor market institutions in both countries. For example, because the unemployment insurance (UI) system in the United States is experience rated, U.S. employers generally incur higher UI taxes when they lay off workers; although German employers face greater regulation of layoffs than do American employers, they incur no tax penalties associated with layoffs. Moreover, German employment protection laws may inhibit the use of layoffs, but other German policies, such as unemployment compensation for workers on short time, facilitate the use of alternatives to layoffs, including work sharing. Elsewhere (Abraham and Houseman 1993, 1994) we present evidence to suggest that, although German employers adjust employment levels more slowly than do their U.S. counterparts in response to demand changes, they make larger shorr run adjustments to average hours per worker. Differences in total labor adjustment tend to be small.

In this chapter we build upon our previous work examining employment and hours adjustment in the former West Germany and the United States. We use an interrelated factor demand model to jointly estimate employment and hours adjustment in the manufacturing sectors of the two countries. Results based on this model strengthen the conclusions drawn in our earlier work.

Because the availability of UI benefits for short-time work in Germany facilitates the use of work sharing as an alternative to layoffs there, we also consider the contribution that short-time work makes to total labor adjustment. In addition, we review evidence on the effects of changes in employment protection laws on labor adjustment in Germany. Finally, we look at whether and to what extent finished goods inventories help to smooth fluctuations in production in Germany and the United States. If labor adjustment costs are greater in Germany than in the United States, as is usually presumed, we would expect finished goods inventories to play a more important buffer role in Germany, thereby mitigating the need to adjust labor input to demand changes there.

\section{THE GERMAN AND U.S. INDUSTRIAL RELATIONS SYSTEMS}

We interpret differences in employment and hours adjustment patterns in Germany and the United States in light of the two countries' labor market institutions, and so begin with an overview of selected features of their industrial relations systems. The German and U.S. industrial relations systems differ in many respects, but the 
most relevant for our present purposes are differences in layoff policies, UI rules, and regulations concerning the use of overtime.

\section{Germany}

In Germany, as in most Western European countries, there is a long tradition of requiring employers to give advance notice of dismissal to individual workers. The first advance notice law in Germany was passed during the 1920's. Today, required periods of notice to individual workers vary from two weeks to six months, depending upon whether the worker holds a blue-collar or a white-collar job and upon his or her seniority and age. ${ }^{4}$

In addition to stipulating advance notice for individual workers, German law gives the works council, a legally mandated body of elected worker representatives, important powers in the event of a collective dismissal. Under current law, employers must keep both the works council and the local employment office advised of any developments that might lead to a collective dismissal over the next twelve months, and must consult the works council "as soon as possible" when contemplating such a layoff. The most important provision of the current law was introduced in 1973 and requires that, in cases of collective dismissal at an establishment normally employing more than 20 employees, management and the works council must negotiate a social plan that stipulates compensation for workers who lose their jobs. In the event that the two parties cannot agree on a social plan, the law provides for binding arbitration. The social plan requirement greatly enhances the works council's power to influence management decisions with respect to employment and hours adjustment.

Although social plans are required only in the event of a collective dismissal, the number of workers who must be laid off for a layoff to fall into this category is not particularly high. For example, prior to 1985 , for establishments with 60 to 250 workers, a collective dismissal was defined as the layoff of 10 percent of the work force over a 30-day period; for establishments employing 500 or more workers, the threshold was just 30 dismissed workers over a 30-day period. The Employment Promotion Act of 1985 raised these thresholds somewhat and gave new enterprises a four-year exemption from the social plan requirement. ${ }^{5}$

Settlements in social plans vary considerably from case to case, and depend upon the worker's tenure and wage, as well as the company's financial condition. A recent study by Hemmer (1988) provides the best available data on the amounts of compensation paid out. In a sample of 145 social plans negotiated between 1980 and 1985, the median settlement was between DM10,000 and DM15,000 per recipient, or about 15 to 25 weeks' pay for a person with average blue-collar industrial earnings. The fact that a social plan is required only in situations involving a mass layoff creates an incentive for the firm to rely on attrition and perhaps on smaller layoffs spread out over time instead of on a mass layoff.

As in the United States, German workers who are laid off are eligible to collect UI benefits. The payroll tax that finances these benefits, however, is not experience 
rated so that, unlike their U.S. counterparts, German employers incur no increase in UI tax liability when they lay off workers. Because of the advance notice and other requirements associated with collective dismissals, temporary layoffs are virtually unknown in Germany. The German UI system does provide for shorttime benefits. With the approval of the Bundesanstalt für Arbeit (Federal Employment Office), firms can reduce employees' hours of work and those employees can collect prorated UI benefits, which are financed in the same way as benefits to laid off workers. Firms applying for short-time benefits must show that other measures for accommodating the fall in demand, such as reducing overtime and rebuilding inventories, have already been taken. ${ }^{6}$

In contrast to U.S. law, German law contains no provision covering overtime premia, which instead are governed by the terms of industry-level collective bargaining agreements. The typical agreement provides for an overtime premium of about 20 percent, which is considerably lower than the 50 percent premium mandated by U.S. law.

Although the availability of subsidized short-time benefits and the low overtime premium that is typical in German collective bargaining agreements can be expected to encourage reliance on hours adjustments by German employers, it should be noted that any change in scheduled hours at an establishment must be approved by the works council. Works councils, however, are generally accommodating in these matters.

\section{The United States}

The siruation with respect to advance notice of layoffs and negotiation over layoffs historically has been quite different in the United States. Prior to 1988, advance notice of layoffs and plant closings was required in only three states: Maine, Wisconsin, and Hawaii. In the absence of any national law requiring advance notice, workers often received little or no warning prior to being let go.? In 1988 the U.S. Congress passed the Worker Adjustment and Retraining Notification Act. The law, which took effect in 1989, requires employers to give workers and state and local government officials 60 days' advance notice before a mass layoff or plant closure. In general, a mass layoff is defined as a layoff of at least one third of the work force at a single site within a 30-day period or a reduction in the hours of at least one third of the work force by at least 50 percent for six months or longer. ${ }^{8}$

The U.S. advance notice law is far weaker than German collective dismissal law. The requirement that employers negotiate a social plan with the works council is widely regarded as the most important in German collective dismissal law. U.S. law does not require that companies consult with worker representatives or pay compensation to laid-off workers. Moreover, even the advance notice requirement in existing U.S. law appears to be having little effect. A recent survey by the General Accounting Office (1993) found that three quarters of all companies that had work force reductions of a sufficient scale to trigger notice requirements either failed to 
file notice or gave less than 60 days' notice. These findings suggest that in most cases companies either slip through the law's large loopholes or simply fail to comply with the law.

Although U.S. employers are not required to make severance payments to laidoff workers, the fact that the U.S. UI system is experience rated means that layoffs may lead to an increase in UI tax liability. For a U.S. employer, the effective UI cost of laying off a worker depends upon three things: His or her weekly benefit amount; the duration of benefit receipt; and the share of benefits for which the employer ultimately pays through higher UI taxes. Weekly benefit amounts average roughly 35 percent of weekly wages; the average duration of benefit receipt varies somewhat over the business cycle, but has averaged about 14 weeks; and, at the margin, a typical employer bears about 60 percent of the cost of benefits paid to laid-off workers (though many employers are already paying the maximum UI tax rate and thus incur no increase in costs if they lay off additional workers). ' Thus, a rough estimate of the UI cost to a typical employer of laying off another worker is about three weeks' wages in the form of increased UI tax liability.

Paying UI benefits to workers whose hours have been reduced is a recent innovation in the United States. Only 17 states have laws allowing prorated payment of UI benefits to workers whose hours are reduced under approved worksharing plans, and most of these laws were passed in 1985 or later. Current U.S. law specifies that nonexempt employees are entitled to a 50 percent wage premium for hours worked in excess of 40 hours per week. Although U.S. employers are typically free to alter work schedules as they choose, both the lack of provision for short-time benefits and the relatively high overtime premium mandated by federal law can be expected to discourage reliance on hours adjustments.

\section{Employment and Hours Adjustment}

Because of the institutional differences just described, we would expect to observe quite different patterns of labor adjustment in Germany and the United States. Employers may adjust labor input along two margins: the number of workers and average hours per worker. Given the higher costs of adjusting employment in Germany, we would expect slower adjustment of employment to changes in the demand for labor in Germany than in the United States. In the event of a downturn, layoffs may be delayed by the requirement that the firm give advance notice and, in the case of a mass layoff, further delayed by the negoriation of a social plan with the works council. Given that mass layoffs are relatively costly in Germany, we would expect greater reliance on attrition to achieve desired work force reductions there than in the United States, and might also expect layoffs to be more spread out over time. In addition, during both downturns and upturns, German employers are likely to delay employment adjustments until they are reasonably certain that any observed change in labor demand will persist.

While we would expect the adjustment of employment to be slower in Germany than in the United States, we would expect greater adjustment of average hours for 
workers in the short run. The fact that employment adjustment costs are typically higher in Germany than in the United States should increase employers' reliance on hours adjustments. In addition, absent works council opposition to schedule changes, the availability of short-time compensation and lower German overtime premia make it less costly for German employers to adjust average hours per worker. ${ }^{10} \mathrm{~A}$ priori, it is unclear whether the adjustment of total labor input is more or less costly in Germany than in the United States, and thus unclear whether German employers are, in fact, less able to adjust labor input to changes in demand.

To analyze this issue empirically, we model the dynamic adjustment of employment and hours to fluctuations in output using the following interrelated factor demand model:

$$
\begin{aligned}
& \ln E_{t}=\alpha_{10}+\alpha_{11} \ln E_{t-1}+\alpha_{12} \ln h_{t-1}+\beta_{1} \ln S_{t}+\phi_{11} t+\phi_{12} t^{2}+\varepsilon_{1 t} \\
& \ln h_{t}=\alpha_{20}+\alpha_{21} \ln E_{t-1}+\alpha_{22} \ln h_{t-1}+\beta_{2} \ln S_{t}+\phi_{21} t+\phi_{22} t^{2}+\varepsilon_{2 t}
\end{aligned}
$$

where $E$ is production employment; $b$ is average hours per production worker; $S$ is shipments; $t$ and $t^{2}$ are time trends; and the $\alpha$ 's, $\beta$ 's and $\phi$ 's are parameters to be estimated. This system of equations allows for the fact that the paths of adjustment of employment and hours may be interdependent; not only does the adjustment of a particular factor depend on changes in shipments, but it also depends on the path of adjustment of other factors. ${ }^{11}$

We estimate this model using quarterly, seasonally adjusted data. ${ }^{12}$ Each equation in the model was fitted independently. Based on the results of Durbin-h tests, we correct for first-order serial correlation in the equation error terms, where appropriate. Separate models were specified for aggregate manufacturing and for eleven disaggregated manufacturing industries in each country. We take care to identify comparably defined industries because we want, insofar as possible, to hold constant technological factors that might affect labor adjustment patterns in drawing cross-county comparisons. ${ }^{13}$ Data limitations unfortunately prevent the inclusion of any nonmanufacturing industries in our analysis. Sources and additional details concerning the data are provided in the data appendix.

We use the parameter estimates from equations (1a) and (lb) to simulate the dynamic effects of a one-unit, permanent shock to shipments on production employment, average production hours, and total production hours. Implied responses over different horizons, along with their associated standard errors, are reported in Table 12.1. ${ }^{14}$ (Selected coefficients from the models underlying these simulations are reported in Table 12.3 of the Appendix.) For aggregate German manufacturing, for example, Table 12.1 shows that a 1 percent decrease (increase) in shipments would result in a 0.17 percent decrease (increase) in production employment, a 0.40 percent decrease (increase) in average production hours, and a 0.57 percent decrease (increase) in total production hours in the quarter contemporaneous to the shock. Assuming the decrease to shipments persists, four quarters 
SUSAN N. HOUSEMAN, KATHARINE G. ABRAHAM

Table 12.1 Simulated Adjustment of Production Employment and Production Hours to a Permanent One-Unit Shock to Shipments in German and U.S.

Manufacturing Industries, 1973-90²

\begin{tabular}{|c|c|c|c|c|c|c|}
\hline \multirow[b]{2}{*}{ Industry/Lag } & \multicolumn{2}{|c|}{ Employment } & \multicolumn{2}{|c|}{ Average Hours } & \multicolumn{2}{|c|}{ Total Hours } \\
\hline & Germany & U.S. & Germany & U.S. & Germany & U.S. \\
\hline \multicolumn{7}{|l|}{ Manufacturing } \\
\hline Current Quarter & $\begin{array}{c}0.17^{*} \\
(0.02)\end{array}$ & $\begin{array}{c}0.54 \\
(0.04)\end{array}$ & $\begin{array}{c}0.40^{\circ} \\
(0.05)\end{array}$ & $\begin{array}{c}0.22 \\
(0.03)\end{array}$ & $\begin{array}{c}0.57^{\circ} \\
(0.06)\end{array}$ & $\begin{array}{c}0.75 \\
(0.05)\end{array}$ \\
\hline 1 Quarter & $\begin{array}{c}0.35^{\circ} \\
(0.04)\end{array}$ & $\begin{array}{c}0.85 \\
(0.05)\end{array}$ & $\begin{array}{c}0.38 \\
(0.06)\end{array}$ & $\begin{array}{c}0.25 \\
(0.03)\end{array}$ & $\begin{array}{c}0.73^{\circ} \\
(0.07)\end{array}$ & $\begin{array}{c}1.11 \\
(0.05)\end{array}$ \\
\hline 2 Quarters & $\begin{array}{c}0.49^{*} \\
(0.06)\end{array}$ & $\begin{array}{c}1.02 \\
(0.05)\end{array}$ & $\begin{array}{c}0.30 \\
(0.06)\end{array}$ & $\begin{array}{c}0.22 \\
(0.03)\end{array}$ & $\begin{array}{c}0.79^{\circ} \\
(0.07)\end{array}$ & $\begin{array}{c}1.24 \\
(0.05)\end{array}$ \\
\hline 4 Quarters & $\begin{array}{c}0.69^{\circ} \\
(0.08)\end{array}$ & $\begin{array}{c}1.11 \\
(0.06)\end{array}$ & $\begin{array}{c}0.17 \\
(0.07)\end{array}$ & $\begin{array}{c}0.12 \\
(0.04)\end{array}$ & $\begin{array}{c}0.85^{\circ} \\
(0.07)\end{array}$ & $\begin{array}{c}1.24 \\
(0.05)\end{array}$ \\
\hline 6 Quarters & $\begin{array}{c}0.81^{\circ} \\
(0.10)\end{array}$ & $\begin{array}{c}1.11 \\
(0.06)\end{array}$ & $\begin{array}{c}0.08 \\
(0.07)\end{array}$ & $\begin{array}{c}0.07 \\
(0.05)\end{array}$ & $\begin{array}{c}0.89^{\circ} \\
(0.08)\end{array}$ & $\begin{array}{c}1.18 \\
(0.06)\end{array}$ \\
\hline \multicolumn{7}{|l|}{ Textiles } \\
\hline Current Quarter & $\begin{array}{r}0.14^{*} \\
(0.02)\end{array}$ & $\begin{array}{c}0.27 \\
(0.05)\end{array}$ & $\begin{array}{c}0.26 \\
(0.05)\end{array}$ & $\begin{array}{c}0.23 \\
(0.07)\end{array}$ & $\begin{array}{c}0.40 \\
(0.05)\end{array}$ & $\begin{array}{c}0.49 \\
(0.08)\end{array}$ \\
\hline 1 Quarter & $\begin{array}{c}0.28 \\
(0.04)\end{array}$ & $\begin{array}{c}0.39 \\
(0.06)\end{array}$ & $\begin{array}{c}0.31 \\
(0.06)\end{array}$ & $\begin{array}{c}0.24 \\
(0.04)\end{array}$ & $\begin{array}{c}0.60 \\
(0.07)\end{array}$ & $\begin{array}{c}0.62 \\
(0.07)\end{array}$ \\
\hline 2 Quarters & $\begin{array}{c}0.41 \\
(0.05)\end{array}$ & $\begin{array}{c}0.42 \\
(0.06)\end{array}$ & $\begin{array}{c}0.30 \\
(0.06)\end{array}$ & $\begin{array}{c}0.21 \\
(0.05)\end{array}$ & $\begin{array}{c}0.71 \\
(0.08)\end{array}$ & $\begin{array}{c}0.64 \\
(0.07)\end{array}$ \\
\hline 4 Quarters & $\begin{array}{c}0.62 \\
(0.08)\end{array}$ & $\begin{array}{c}0.43 \\
(0.07)\end{array}$ & $\begin{array}{c}0.21 \\
(0.07)\end{array}$ & $\begin{array}{c}0.19 \\
(0.05)\end{array}$ & $\begin{array}{c}0.83 \\
(0.10)\end{array}$ & $\begin{array}{c}0.62 \\
(0.08)\end{array}$ \\
\hline 6 Quarters & $\begin{array}{c}0.77^{\circ} \\
(0.11)\end{array}$ & $\begin{array}{c}0.43 \\
(0.07)\end{array}$ & $\begin{array}{c}0.13 \\
(0.08)\end{array}$ & $\begin{array}{c}0.19 \\
(0.06)\end{array}$ & $\begin{array}{c}0.90 \\
(0.12)\end{array}$ & $\begin{array}{c}0.62 \\
(0.08)\end{array}$ \\
\hline \multicolumn{7}{|l|}{ Apparel } \\
\hline Current Quarter & $\begin{array}{c}0.17 \\
(0.02)\end{array}$ & $\begin{array}{c}0.13 \\
(0.04)\end{array}$ & $\begin{array}{c}0.15 \\
(0.05)\end{array}$ & $\begin{array}{c}0.06 \\
(0.02)\end{array}$ & $\begin{array}{c}0.32 \\
(0.06)\end{array}$ & $\begin{array}{c}0.19 \\
(0.05)\end{array}$ \\
\hline 1 Quarter & $\begin{array}{c}0.35 \\
(0.04)\end{array}$ & $\begin{array}{c}0.21 \\
(0.06)\end{array}$ & $\begin{array}{c}0.15 \\
(0.06)\end{array}$ & $\begin{array}{c}0.08 \\
(0.03)\end{array}$ & $\begin{array}{c}0.50^{\circ} \\
(0.07)\end{array}$ & $\begin{array}{c}0.29 \\
(0.06)\end{array}$ \\
\hline 2 Quarters & $\begin{array}{c}0.50^{\circ} \\
(0.05)\end{array}$ & $\begin{array}{c}0.26 \\
(0.07)\end{array}$ & $\begin{array}{c}0.10 \\
(0.06)\end{array}$ & $\begin{array}{c}0.09 \\
(0.03)\end{array}$ & $\begin{array}{c}0.60^{\circ} \\
(0.09)\end{array}$ & $\begin{array}{c}0.35 \\
(0.07)\end{array}$ \\
\hline 4 Quarters & $\begin{array}{c}0.72^{\circ} \\
(0.08)\end{array}$ & $\begin{array}{c}0.31 \\
(0.09)\end{array}$ & $\begin{array}{c}-0.01 \\
(0.06)\end{array}$ & $\begin{array}{c}0.08 \\
(0.04)\end{array}$ & $\begin{array}{c}0.71^{\circ} \\
(0.10)\end{array}$ & $\begin{array}{c}0.39 \\
(0.08)\end{array}$ \\
\hline 6 Quarters & $\begin{array}{c}0.86^{\circ} \\
(0.10)\end{array}$ & $\begin{array}{c}0.33 \\
(0.12)\end{array}$ & $\begin{array}{c}-0.09 \\
(0.06)\end{array}$ & $\begin{array}{c}0.07 \\
(0.05)\end{array}$ & $\begin{array}{c}0.77^{*} \\
(0.12)\end{array}$ & $\begin{array}{c}0.39 \\
(0.10)\end{array}$ \\
\hline \multicolumn{7}{|l|}{ Paper' } \\
\hline Current Quarter & $\begin{array}{c}0.03^{\circ} \\
(0.04)\end{array}$ & $\begin{array}{c}0.25 \\
(0.06)\end{array}$ & $\begin{array}{c}0.30^{\circ} \\
(0.06)\end{array}$ & $\begin{array}{c}0.06 \\
(0.03)\end{array}$ & $\begin{array}{c}0.33 \\
(0.07)\end{array}$ & $\begin{array}{c}0.31 \\
(0.06)\end{array}$ \\
\hline 1 Quarter & $\begin{array}{c}0.11^{\circ} \\
(0.07)\end{array}$ & $\begin{array}{c}0.37 \\
(0.07)\end{array}$ & $\begin{array}{c}0.33^{\circ} \\
(0.09)\end{array}$ & $\begin{array}{c}0.07 \\
(0.04)\end{array}$ & $\begin{array}{c}0.44 \\
(0.11)\end{array}$ & $\begin{array}{c}0.44 \\
(0.08)\end{array}$ \\
\hline 2 Quarters & $\begin{array}{c}0.18 \\
(0.11)\end{array}$ & $\begin{array}{c}0.42 \\
(0.07)\end{array}$ & $\begin{array}{c}0.32^{*} \\
(0.10)\end{array}$ & $\begin{array}{c}0.06 \\
(0.05)\end{array}$ & $\begin{array}{c}0.51 \\
(0.15)\end{array}$ & $\begin{array}{c}0.48 \\
(0.09)\end{array}$ \\
\hline
\end{tabular}


Table 12.1 (Continued)

\begin{tabular}{|c|c|c|c|c|c|c|}
\hline \multirow[b]{2}{*}{ Industry/Lag } & \multicolumn{2}{|c|}{ Employment } & \multicolumn{2}{|c|}{ Average Hours } & \multicolumn{2}{|c|}{ Total Hours } \\
\hline & Germany & U.S. & Germany & U.S. & Germany & U.S. \\
\hline 4 Quarters & $\begin{array}{c}0.31 \\
(0.17)\end{array}$ & $\begin{array}{c}0.42 \\
(0.07)\end{array}$ & $\begin{array}{c}0.30^{\circ} \\
(0.11)\end{array}$ & $\begin{array}{c}0.04 \\
(0.06)\end{array}$ & $\begin{array}{c}0.60 \\
(0.20)\end{array}$ & $\begin{array}{c}0.46 \\
(0.11)\end{array}$ \\
\hline 6 Quarters & $\begin{array}{c}0.40 \\
(0.22)\end{array}$ & $\begin{array}{c}0.41 \\
(0.07)\end{array}$ & $\begin{array}{c}0.27 \\
(0.11)\end{array}$ & $\begin{array}{c}0.03 \\
(0.07)\end{array}$ & $\begin{array}{c}0.68 \\
(0.24)\end{array}$ & $\begin{array}{c}0.44 \\
(0.12)\end{array}$ \\
\hline \multicolumn{7}{|l|}{ Printing } \\
\hline Current Quarter & $\begin{array}{r}0.20^{\circ} \\
(0.02)\end{array}$ & $\begin{array}{c}0.06 \\
(0.02)\end{array}$ & $\begin{array}{c}0.16^{\circ} \\
(0.04)\end{array}$ & $\begin{array}{c}0.04 \\
(0.02)\end{array}$ & $\begin{array}{c}0.36^{\circ} \\
(0.05)\end{array}$ & $\begin{array}{c}0.10 \\
(0.02)\end{array}$ \\
\hline \multirow[t]{2}{*}{1 Quarter } & $0.38^{\circ}$ & 0.12 & 0.10 & 0.06 & $0.49^{\circ}$ & 0.18 \\
\hline & $(0.04)$ & $(0.03)$ & $(0.03)$ & $(0.02)$ & $(0.05)$ & $(0.03)$ \\
\hline \multirow[t]{2}{*}{2 Quarters } & $0.52^{\circ}$ & 0.19 & 0.05 & 0.07 & $0.57^{\circ}$ & 0.26 \\
\hline & $(0.05)$ & $(0.03)$ & $(0.03)$ & $(0.02)$ & $(0.05)$ & $(0.04)$ \\
\hline \multirow[t]{2}{*}{4 Quarters } & $0.72^{\circ}$ & 0.30 & $-0.03^{*}$ & 0.07 & $0.69^{\circ}$ & 0.36 \\
\hline & $(0.05)$ & $(0.04)$ & $(0.03)$ & $(0.02)$ & $(0.05)$ & $(0.05)$ \\
\hline \multirow[t]{2}{*}{6 Quarters } & $0.84^{\circ}$ & 0.37 & $-0.09^{\circ}$ & 0.06 & $0.76^{\circ}$ & 0.44 \\
\hline & & & & & & \\
\hline \multicolumn{7}{|l|}{ Leather } \\
\hline \multirow[t]{2}{*}{ Current Quarter } & 0.19 & 0.21 & $0.28^{\circ}$ & 0.09 & 0.47 & 0.31 \\
\hline & $(0.03)$ & $(0.04)$ & $(0.06)$ & $(0.03)$ & $(0.07)$ & $(0.05)$ \\
\hline \multirow[t]{2}{*}{1 Quarter } & 0.36 & 0.35 & $0.28^{\circ}$ & 0.11 & 0.64 & 0.46 \\
\hline & $(0.04)$ & $(0.07)$ & $(0.07)$ & $(0.04)$ & $(0.08)$ & $(0.07)$ \\
\hline \multirow[t]{2}{*}{2 Quarters } & 0.49 & 0.43 & 0.21 & 0.10 & 0.70 & 0.53 \\
\hline & $(0.05)$ & $(0.10)$ & $(0.07)$ & $(0.04)$ & $(0.08)$ & $(0.10)$ \\
\hline \multirow[t]{2}{*}{4 Quarters } & 0.65 & 0.51 & 0.07 & 0.06 & 0.73 & 0.57 \\
\hline & $(0.06)$ & $(0.17)$ & $(0.06)$ & $(0.05)$ & $(0.08)$ & $(0.15)$ \\
\hline \multirow[t]{2}{*}{ 6 Quarters } & 0.74 & 0.53 & -0.01 & 0.04 & 0.73 & 0.57 \\
\hline & $(0.07)$ & $(0.22)$ & $(0.06)$ & $(0.06)$ & $(0.08)$ & $(0.18)$ \\
\hline \multicolumn{7}{|c|}{ Stone, Clay, and Glass } \\
\hline \multirow[t]{2}{*}{ Current Quarter } & $0.12^{*}$ & 0.32 & 0.19 & 0.13 & $0.31^{*}$ & 0.44 \\
\hline & $(0.01)$ & $(0.04)$ & $(0.03)$ & $(0.02)$ & $(0.03)$ & $(0.04)$ \\
\hline \multirow[t]{2}{*}{1 Quarter } & $0.23^{\circ}$ & 0.54 & 0.22 & 0.17 & $0.45^{\circ}$ & 0.71 \\
\hline & $(0.02)$ & $(0.06)$ & $(0.03)$ & $(0.02)$ & $(0.03)$ & $(0.05)$ \\
\hline \multirow[t]{2}{*}{2 Quarters } & $0.32^{\circ}$ & 0.68 & 0.21 & 0.17 & $0.53^{\circ}$ & 0.85 \\
\hline & $(0.03)$ & $(0.07)$ & $(0.03)$ & $(0.02)$ & $(0.04)$ & $(0.06)$ \\
\hline \multirow[t]{2}{*}{4 Quarters } & $0.46^{\circ}$ & 0.83 & 0.18 & 0.12 & $0.64^{\circ}$ & 0.95 \\
\hline & $(0.04)$ & $(0.08)$ & $(0.03)$ & $(0.03)$ & $(0.05)$ & $(0.06)$ \\
\hline \multirow[t]{2}{*}{6 Quarters } & $0.58^{\circ}$ & 0.87 & 0.14 & 0.08 & $0.72^{\circ}$ & 0.96 \\
\hline & $(0.05)$ & $(0.08)$ & $(0.03)$ & $(0.04)$ & $(0.06)$ & $(0.07)$ \\
\hline \multicolumn{7}{|l|}{ Primary Metals } \\
\hline \multirow[t]{2}{*}{ Current Quarter } & $0.08^{\circ}$ & 0.37 & $0.43^{\circ}$ & 0.15 & 0.51 & 0.52 \\
\hline & $(0.02)$ & $(0.04)$ & $(0.05)$ & $(0.01)$ & $(0.05)$ & $(0.04)$ \\
\hline
\end{tabular}


SUSAN N. HOUSEMAN, KATHARINE G. ABRAHAM

Table 12.1 (Continued)

\begin{tabular}{|c|c|c|c|c|c|c|}
\hline \multirow[b]{2}{*}{ Industry/Lag } & \multicolumn{2}{|c|}{ Employment } & \multicolumn{2}{|c|}{ Average Hours } & \multicolumn{2}{|c|}{ Total Hours } \\
\hline & Germany & U.S. & Germany & U.S. & Germany & U.S. \\
\hline 1 Quarter & $\begin{array}{c}0.16^{\circ} \\
(0.04)\end{array}$ & $\begin{array}{c}0.53 \\
(0.04)\end{array}$ & $\begin{array}{c}0.34^{\circ} \\
(0.05)\end{array}$ & $\begin{array}{c}0.15 \\
(0.02)\end{array}$ & $\begin{array}{c}0.50^{\circ} \\
(0.06)\end{array}$ & $\begin{array}{c}0.68 \\
(0.04)\end{array}$ \\
\hline 2 Quarters & $\begin{array}{c}0.22^{\circ} \\
(0.05)\end{array}$ & $\begin{array}{c}0.59 \\
(0.04)\end{array}$ & $\begin{array}{r}0.32^{\circ} \\
(0.05)\end{array}$ & $\begin{array}{c}0.11 \\
(0.02)\end{array}$ & $\begin{array}{c}0.54^{\circ} \\
(0.06)\end{array}$ & $\begin{array}{c}0.70 \\
(0.04)\end{array}$ \\
\hline 4 Quarters & $\begin{array}{c}0.31^{\circ} \\
(0.08)\end{array}$ & $\begin{array}{c}0.61 \\
(0.05)\end{array}$ & $\begin{array}{c}0.28^{*} \\
(0.06)\end{array}$ & $\begin{array}{c}0.06 \\
(0.03)\end{array}$ & $\begin{array}{c}0.59 \\
(0.08)\end{array}$ & $\begin{array}{c}0.67 \\
(0.05)\end{array}$ \\
\hline 6 Quarters & $\begin{array}{c}0.36^{\circ} \\
(0.10)\end{array}$ & $\begin{array}{c}0.61 \\
(0.06)\end{array}$ & $\begin{array}{c}0.26^{\circ} \\
(0.06)\end{array}$ & $\begin{array}{c}0.04 \\
(0.04)\end{array}$ & $\begin{array}{c}0.62 \\
(0.10)\end{array}$ & $\begin{array}{c}0.65 \\
(0.04)\end{array}$ \\
\hline \multicolumn{7}{|c|}{ Nonelectrical Machinery } \\
\hline Current Quarter & $\begin{array}{c}0.01^{*} \\
(0.01)\end{array}$ & $\begin{array}{c}0.52 \\
(0.07)\end{array}$ & $\begin{array}{c}0.13 \\
(0.04)\end{array}$ & $\begin{array}{c}0.16 \\
(0.03)\end{array}$ & $\begin{array}{c}0.14^{\circ} \\
(0.04)\end{array}$ & $\begin{array}{c}0.68 \\
(0.08)\end{array}$ \\
\hline 1 Quarter & $\begin{array}{c}0.03^{\circ} \\
(0.03)\end{array}$ & $\begin{array}{c}0.84 \\
(0.09)\end{array}$ & $\begin{array}{c}0.18 \\
(0.06)\end{array}$ & $\begin{array}{c}0.21 \\
(0.04)\end{array}$ & $\begin{array}{c}0.21^{\circ} \\
(0.06)\end{array}$ & $\begin{array}{c}1.05 \\
(0.09)\end{array}$ \\
\hline 2 Quarters & $\begin{array}{c}0.05^{\circ} \\
(0.04)\end{array}$ & $\begin{array}{c}1.03 \\
(0.09)\end{array}$ & $\begin{array}{c}0.21 \\
(0.06)\end{array}$ & $\begin{array}{c}0.20 \\
(0.05)\end{array}$ & $\begin{array}{c}0.26^{\circ} \\
(0.07)\end{array}$ & $\begin{array}{c}1.23 \\
(0.09)\end{array}$ \\
\hline 4 Quarters & $\begin{array}{c}0.07^{\circ} \\
(0.07)\end{array}$ & $\begin{array}{c}1.18 \\
(0.10)\end{array}$ & $\begin{array}{c}0.22 \\
(0.07)\end{array}$ & $\begin{array}{c}0.11 \\
(0.05)\end{array}$ & $\begin{array}{c}0.29^{\circ} \\
(0.09)\end{array}$ & $\begin{array}{c}1.29 \\
(0.09)\end{array}$ \\
\hline 6Q Quarters & $\begin{array}{c}0.09^{\circ} \\
(0.11)\end{array}$ & $\begin{array}{c}1.18 \\
(0.10)\end{array}$ & $\begin{array}{c}0.21 \\
(0.07)\end{array}$ & $\begin{array}{c}0.04 \\
(0.06)\end{array}$ & $\begin{array}{c}0.31^{\circ} \\
(0.11)\end{array}$ & $\begin{array}{c}1.23 \\
(0.08)\end{array}$ \\
\hline \multicolumn{7}{|l|}{ Electrical Equipment } \\
\hline Current Quarter & $\begin{array}{c}0.13^{\circ} \\
(0.03)\end{array}$ & $\begin{array}{c}0.37 \\
(0.06)\end{array}$ & $\begin{array}{c}0.52^{\circ} \\
(0.06)\end{array}$ & $\begin{array}{c}0.07 \\
(0.02)\end{array}$ & $\begin{array}{c}0.65^{\circ} \\
(0.06)\end{array}$ & $\begin{array}{c}0.44 \\
(0.06)\end{array}$ \\
\hline 1 Quarter & $\begin{array}{c}0.28^{*} \\
(0.07)\end{array}$ & $\begin{array}{c}0.63 \\
(0.07)\end{array}$ & $\begin{array}{c}0.59^{\circ} \\
(0.07)\end{array}$ & $\begin{array}{c}0.09 \\
(0.03)\end{array}$ & $\begin{array}{c}0.87 \\
(0.09)\end{array}$ & $\begin{array}{c}0.72 \\
(0.08)\end{array}$ \\
\hline 2 Quarters & $\begin{array}{c}0.40^{\circ} \\
(0.11)\end{array}$ & $\begin{array}{c}0.79 \\
(0.08)\end{array}$ & $\begin{array}{c}0.54^{\circ} \\
(0.08)\end{array}$ & $\begin{array}{c}0.09 \\
(0.03)\end{array}$ & $\begin{array}{c}0.94 \\
(0.11)\end{array}$ & $\begin{array}{c}0.88 \\
(0.09)\end{array}$ \\
\hline 4 Quarters & $\begin{array}{c}0.54 \\
(0.18)\end{array}$ & $\begin{array}{c}0.92 \\
(0.10)\end{array}$ & $\begin{array}{c}0.41^{\circ} \\
(0.11)\end{array}$ & $\begin{array}{c}0.05 \\
(0.04)\end{array}$ & $\begin{array}{c}0.95 \\
(0.12)\end{array}$ & $\begin{array}{c}0.97 \\
(0.10)\end{array}$ \\
\hline 6Q Quarters & $\begin{array}{c}0.61 \\
(0.25)\end{array}$ & $\begin{array}{c}0.93 \\
(0.12)\end{array}$ & $\begin{array}{c}0.33 \\
(0.15)\end{array}$ & $\begin{array}{c}0.02 \\
(0.05)\end{array}$ & $\begin{array}{c}0.94 \\
(0.13)\end{array}$ & $\begin{array}{c}0.95 \\
(0.11)\end{array}$ \\
\hline \multicolumn{7}{|l|}{ Autos } \\
\hline Current Quarter & $\begin{array}{c}0.13^{\circ} \\
(0.01)\end{array}$ & $\begin{array}{c}0.43 \\
(0.04)\end{array}$ & $\begin{array}{c}0.48^{\circ} \\
(0.05)\end{array}$ & $\begin{array}{c}0.19 \\
(0.02)\end{array}$ & $\begin{array}{c}0.61 \\
(0.06)\end{array}$ & $\begin{array}{c}0.62 \\
(0.04)\end{array}$ \\
\hline 1 Quarter & $\begin{array}{r}0.29^{*} \\
(0.03)\end{array}$ & $\begin{array}{c}0.60 \\
(0.04)\end{array}$ & $\begin{array}{c}0.41^{\circ} \\
(0.06)\end{array}$ & $\begin{array}{c}0.18 \\
(0.02)\end{array}$ & $\begin{array}{c}0.70 \\
(0.07)\end{array}$ & $\begin{array}{c}0.79 \\
(0.03)\end{array}$ \\
\hline 2 Quarters & $\begin{array}{r}0.42^{\circ} \\
(0.04)\end{array}$ & $\begin{array}{c}0.67 \\
(0.04)\end{array}$ & $\begin{array}{c}0.35^{\circ} \\
(0.07)\end{array}$ & $\begin{array}{c}0.16 \\
(0.02)\end{array}$ & $\begin{array}{c}0.77 \\
(0.08)\end{array}$ & $\begin{array}{c}0.82 \\
(0.03)\end{array}$ \\
\hline 4 Quarters & $\begin{array}{c}0.63 \\
(0.05)\end{array}$ & $\begin{array}{c}0.71 \\
(0.04)\end{array}$ & $\begin{array}{c}0.25 \\
(0.07)\end{array}$ & $\begin{array}{c}0.11 \\
(0.02)\end{array}$ & $\begin{array}{c}0.89 \\
(0.10)\end{array}$ & $\begin{array}{c}0.82 \\
(0.04)\end{array}$ \\
\hline 6Q Quarters & $\begin{array}{c}0.78 \\
(0.07)\end{array}$ & $\begin{array}{c}0.72 \\
(0.05)\end{array}$ & $\begin{array}{c}0.19 \\
(0.08)\end{array}$ & $\begin{array}{c}0.10 \\
(0.02)\end{array}$ & $\begin{array}{c}0.97 \\
(0.13)\end{array}$ & $\begin{array}{c}0.82 \\
(0.04)\end{array}$ \\
\hline
\end{tabular}


Table 12.1 (Continued)

\begin{tabular}{|c|c|c|c|c|c|c|}
\hline \multirow[b]{2}{*}{ Industry/Lag } & \multicolumn{2}{|c|}{ Employment } & \multicolumn{2}{|c|}{ Average Hours } & \multicolumn{2}{|c|}{ Total Hours } \\
\hline & Germany & U.S. & Germany & U.S. & Germany & U.S. \\
\hline \multicolumn{7}{|l|}{ Instruments } \\
\hline \multirow[t]{2}{*}{ Current Quarter } & 0.13 & 0.20 & 0.13 & 0.11 & 0.26 & 0.30 \\
\hline & $(0.03)$ & $(0.05)$ & $(0.03)$ & $(0.03)$ & $(0.04)$ & $(0.06)$ \\
\hline \multirow[t]{2}{*}{1 Quarter } & 0.26 & 0.38 & 0.14 & 0.17 & 0.40 & 0.56 \\
\hline & $(0.05)$ & $(0.09)$ & $(0.04)$ & $(0.05)$ & $(0.06)$ & $(0.10)$ \\
\hline \multirow[t]{2}{*}{2 Quarters } & 0.36 & 0.55 & 0.12 & 0.20 & 0.48 & 0.75 \\
\hline & $(0.06)$ & $(0.12)$ & $(0.04)$ & $(0.06)$ & $(0.06)$ & $(0.14)$ \\
\hline \multirow[t]{2}{*}{4 Quarters } & 0.49 & 0.78 & $0.05^{\circ}$ & 0.22 & $0.54^{\circ}$ & 1.00 \\
\hline & $(0.07)$ & $(0.19)$ & $(0.04)$ & $(0.06)$ & $(0.07)$ & $(0.20)$ \\
\hline \multirow[t]{2}{*}{6 Quarters } & 0.55 & 0.91 & $0.01^{\prime \prime}$ & 0.20 & $0.56^{\circ}$ & 1.11 \\
\hline & $(0.09)$ & $(0.25)$ & $(0.05)$ & $(0.07)$ & $(0.08)$ & $(0.25)$ \\
\hline
\end{tabular}

Notes:

${ }^{2}$ Standard errors are in parentheses. An asrerisk denores that German-U.S. difference is significant at 0.05 level, two-tailed rest.

${ }^{b}$ German paper industry results are for the 1973-1985 period.

following the initial 1 percent shock, employment would have decreased an estimated 0.69 percent, average hours would be 0.17 percent lower, and so total hours would be 0.85 percent lower.

The results for aggregate manufacturing indicate that German employers rely relatively more on changes in hours per worker to adjust total labor input in the short run, whereas even in the short run U.S. employers rely primarily on adjustments to the number of workers. Although employment adjustment is significantly greater in the United States than in Germany across all time horizons examined here, the adjustment of average hours is greater in Germany, significantly so in the contemporaneous quarter. In the quarter that a shock to shipments occurs, average hours adjustment accounts for about 70 percent of total hours adjustment in Germany, whereas in the United States employment adjustment accounts for about 70 percent of initial adjustment. As expected, average hours adjustment declines both in an absolute and in a relative sense in Germany over time, as employers alter employment in response to a permanent shock. Figure 12.1 depicts these quite different patterns of employment and hours adjustment in Germany and the United States.

Although the adjustment of average hours is greater in German than in U.S. aggregate manufacturing, this greater average hours adjustment does not fully compensate for the smaller adjustment of employment in the short run, and total hours adjustment is significantly smaller in German manufacturing up to six quarters after the shock. Results for aggregate manufacturing may be somewhat misleading, however, if the composition of the manufacturing sector is different in the two countries and adjustment patterns differ substantially across detailed industries within countries. To investigate this possibility, we estimate employment 


\section{German manufacturing}

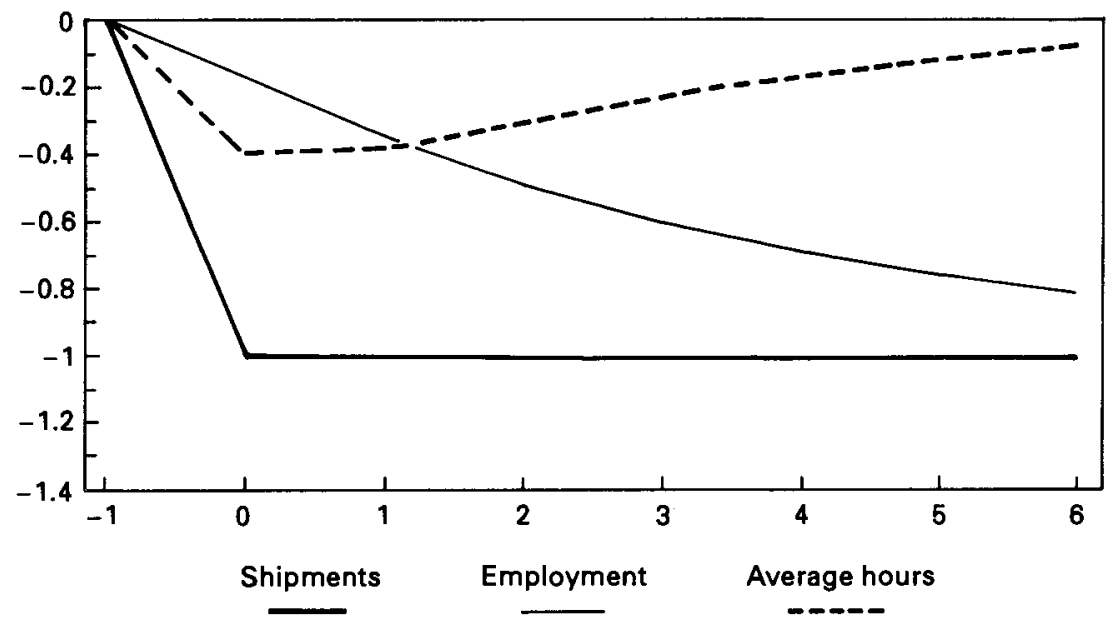

U.S. manufacturing

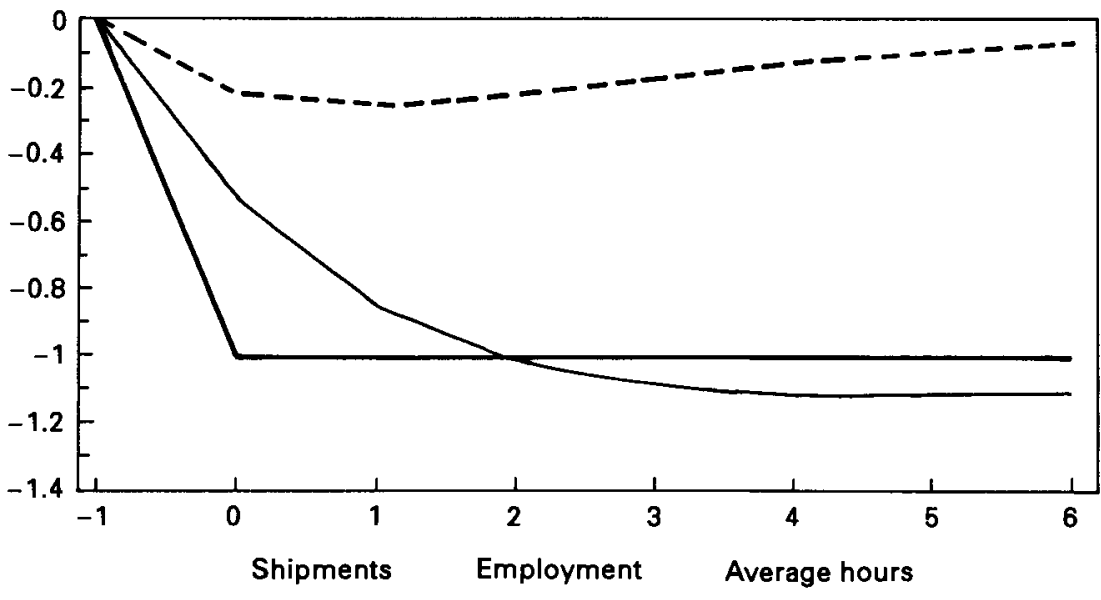

Figure 12.1 Simulared Adjustment of Production Employment and Average Production Hours to a Permanent One-Unit Negative Shock to Shipments

and hours adjustment models for ten manufacturing industries for which we could develop a clean concordance between the German and U.S. data. Because of economists' and policymakers' interest in the automotive sector, we also include that industry in our comparison. ${ }^{15}$

When we examine the results for the disaggregated industries a somewhat different picture emerges. For only two industries - stone/clay/glass and nonelectri- 
cal machinery-is short-run total hours adjustment significantly greater in the United States than in Germany. In five of the eleven industries-paper, leather, primary metals, electrical equipment, and autos-we generally observe significantly greater employment adjustment in the United States and significantly greater average hours adjustment in Germany over short time horizons. In these industries, however, the greater initial adjustment of average hours in Germany appears to compensate for the slower adjustment of employment levels, and the adjustment of total labor input is not significantly different in the two countries. In another three industries-textiles, apparel, and instruments-adjustment patterns are quite similar in the two countries; the short-run adjustment of employment, average hours, and total hours does not differ significantly between Germany and the United States. Finally, in one industry, printing, the adjustment of total hours is actually significantly greater in Germany than in the United States, owing to the significantly greater short-run adjustment of employment in Germany.

In sum, we find that, contrary to popular belief, German manufacturing industries generally adjust labor input as quickly as do U.S. manufacturing industries in response to demand shocks. In most industries short-run employment adjustment is smaller in Germany than in the United States, often significantly so. In most of these industries, however, significantly greater short-run average hours adjustment compensates for the slower adjustment of employment, and there is no significant difference in total hours adjustment.

These results are consistent with those reported in earlier studies comparing employment and hours adjustment in German and U.S. manufacturing industries. Houseman (1988) and Kohler and Sengenberger (1983) studied adjustment in steel and autos, respectively. Both found that German employers adjust employment levels less, but average hours per worker more, in the short run in response to demand shocks. In Abraham and Houseman (1993), we found that employment adjustment generally was significantly slower in the German than in the U.S. manufacturing industries studied, but that total hours adjustment was more similar and often insignificantly different, implying that average hours adjustment was generally greater in Germany. ${ }^{16}$

One way of inferring the effects of German employment protection laws is to compare, as we have just done, employment and hours adjustment in Germany with that in another country, such as the United States, in which there is little regulation of layoffs. Another way of inferring the effects of these laws is to test for changes in employment adjustment that coincide with major changes in employment protection laws. If these laws have a major effect on the way German employers adjust employment, we would expect the speed of employment adjustment to slow following the imposition of more stringent regulations and, conversely, to increase following the relaxation of regulations.

Recent history offers two such events in Germany. The first is the introduction of the requirement that employers negotiate a social plan with the works council in the event of a mass layoff, which was embodied in the 1972 Amendments to the Works Constitution Act. This social plan requirement is widely regarded as among 
the most important provisions in German employment law. In Abraham and Houseman (1993), however, we report evidence to suggest that this law had, at most, a marginal effect on employer behavior. Even before the social plan requirement was enacted, employers in the German manufacturing sector relied primarily on the adjustment of average hours per worker, and very little on that of employment levels, to vary labor input in the short run.

Some observers have suggested that German adjustment patrerns were greatly altered by this new requirement. Legislation such as the 1972 amendments to the Works Constitution Act often is treated as an exogenous event that forces significant changes in the typical employer's behavior. It may be more realistic, however, to treat such legislation as a codification of what has come to be viewed as best practice. If this view is correct, the amendments to the Works Constitution Act may have forced changes in the behavior of some marginal employers whose previous behavior lay outside the norm, but are unlikely to have caused major changes in the behavior of the typical employer.

The 1985 Employment Promotion Act, which weakened employment protection, was a second significant change in German law. This legislation exempted new employers from the requirements of negotiating a social plan, raised the threshold that defines a mass layoff, and relaxed restrictions on the use of temporary workers who are not subject to the laws' provisions. Again, at least some observers have characterized these as significant changes. In Abraham and Houseman (1994), however, we find no change in the speed of adjustment of employment or hours after 1985. This finding echoes that of Kraft (1990), who also finds no evidence of a change in the speed of employment adjustment after 1985 in tests based on data for 21 German manufacturing industries.

\section{SHORT-TIME WORK IN GERMANY}

We have shown that in the German manufacturing sector employers primarily vary the hours that their employees work, rather than the number of employees they hire, to adjust labor input to demand changes in the short run. In contrast, American employers extensively adjust employment to changes in demand conditions, even in the short run. Unemployment compensation for short-time work is an important component of the German UI system and facilitates the use of hours adjustment there, whereas most states in the United States do not offer benefits to workers on short time. Below we assess the importance of short-time work to overall labor adjustment in Germany and evaluate the relative merits of short-time work as an alternative to layoffs.

Figure 12.2 provides some evidence that fluctuations in short time are a significant factor in German adjustment. The figure depicts the percent of workers in German manufacturing on short-time work from 1973 to 1990 using seasonally adjusted monthly data. During good years few workers are on short time. The number rises sharply during recessions. At the trough of the recession in the mid1970 's about 16 percent of manufacturing workers were on short time. Even at the 


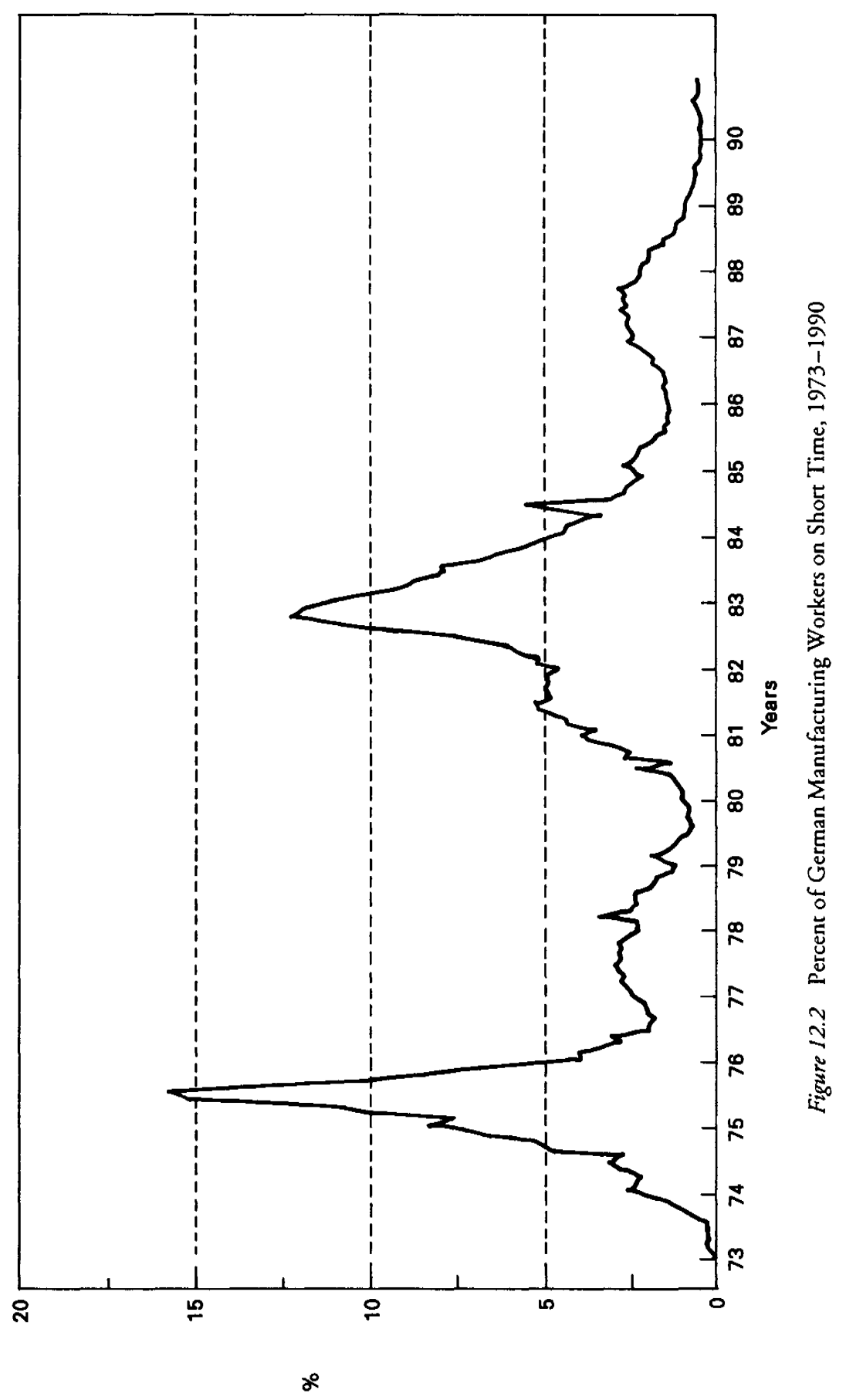


trough of the recession in the early $1980^{\prime}$ 's, which was considerably milder than the earlier recession, over 12 percent of manufacturing workers were on short time.

In earlier work (Abraham and Houseman 1993), we have attempted to characterize the contribution of variation in short-time hours to observed labor adjustment in a somewhat more formal fashion. Our general strategy has been to ask how the adjustment of total hours would have differed had no workers been placed on short time, assuming that employers' adjustment behavior otherwise remained unchanged. We have addressed this question by comparing alternative models of total hours adjustment fit using as our hours measure, first, actual total production hours and, second, the hypothetical total number of production hours obrained by adding hours of short-time compensation paid to the number of production hours actually worked. The results of this sort of exercise can be used to answer questions concerning the share of the total adjustment of hours in response to a shock to shipments accounted for by short time hours.

In Abraham and Houseman (1993), we reported finite distributed lag models of hours adjustment, with and without hours changes artributable to short time, to changes in shipments, fit using data for each of nine disaggregated manufacturing industries covering the 1974 to 1984 time period. The share of current quarter hours adjustment attributable to variation in short time hours averaged about 45 percent and that at lags of one to two quarters averaged in excess of 60 percent. In Abraham and Houseman (1994), we used Koyck models fit with data for the 1973 to 1990 period to assess the contribution of short-time to hours adjustment in the manufacturing sector as a whole. Our estimates implied that, absent the hours changes directly associated with receipt of short time compensation, the current quarter adjustment of total hours to a change in production would have been 40 percent smaller than that actually observed.

As a check on the robustness of the conclusions drawn from our earlier work, we also have estimated a more complete set of hours adjustment models for the 1973 to 1990 time period. This new estimation added models for the full set of disaggregated manufacturing industries for which the requisite data could be obtained and, for closer comparability with the work reported in the present paper, substituted shipments for production as the measure of output, but otherwise used the same approach as Abraham and Houseman (1994). Both for manufacturing as a whole and for each of the seven disaggregated manufacturing industries for which the models could be estimated, we again find that variation in short-time hours makes an important contribution to observed labor adjustment. ${ }^{17}$

Benefits for short-time work in Germany are intended primarily, though not exclusively, for workers affected by temporary reductions in demand. In the United States the structure of the UI system encourages the use of temporary layoffs rather than short-time work during downturns in demand. Temporary layoffs, which are common in the United States, are virtually unknown in Germany. From the employer's perspective, there is a sense in which the use of short time and the use of temporary layoffs are close functional substitutes. Both allow a temporary 
reduction in labor costs during a period of slack demand. There are, however, important respects in which the two differ.

First, a temporary layoff may significantly disrupt the production process. Unless the temporary layoff affects the entire work force, it is likely to require a substantial reorganization of work assignments. If senior employees enjoy bumping rights, laying off even a small number of workers may lead to a large number of job reassignments. When workers are later recalled, productivity may suffer as workers who have been away from the job for an extended period become reacclimated to the work they are doing.

Second, there is a significant risk that employees placed on temporary layoff will not be available for recall. Rough calculations based on the findings reported in Katz and Meyer (1990) indicate that, over the duration of a temporary layoff that lasts thirteen weeks, 25 percent of workers on temporary layoff take a new job; over the duration of a 26 -week temporary layoff, 40 percent of those on layoff take a new job. ${ }^{18}$ If workers who had been temporarily laid off do not return, the firm must incur the costs of hiring and training replacement workers. The costs associated with hiring and training new employees largely could be avoided if workers were placed on short time instead of on temporary layoff."

Moreover, short time and temporary layoffs are not the same from the employee's perspective. Workers on temporary layoff are likely to face great uncertainty about whether they will ever be recalled. Findings reported by Katz and Meyer indicate that, among laid-off workers who initially believe that they will be recalled, only about 70 percent end up returning to their previous employer. ${ }^{20}$ This low percentage in part reflects the fact that some workers choose to take new jobs, but also occurs because many workers never receive recall notices. Rough calculations based on Karz and Meyer's econometric analysis of layoff spells suggests that as many as 25 percent of workers who initially believe that their layoff spell will be temporary do not receive a recall notice within a year following the layoff. ${ }^{21}$ Workers on temporary layoff who are never recalled experience longer than average unemployment spells, in part because they are less likely to look for new work than workers who are certain their layoff is permanent and in part because potential employers are reluctant to hire someone who may quit if recalled to their previous job. These lengthy spells of unemployment represent a loss of income for the individual workers and a loss of resources to society.

Extensive reliance on layoffs is also less equitable than work sharing, for it concentrates the costs of adjustment on a relatively small number of workers who suffer large losses of income and other job-related benefits. Short-time work arrangements spread the costs of adjustment more evenly across members of the work force.

Short-time work may be used to accommodate structural as well as cyclical downturns. In a permanent decline in demand, the use of short-time work does not prevent employment reductions; rather, the temporary use of hours reduction measures can help an employer achieve work force reductions with minimal resort to layoffs. By extending the time over which these work force reductions occur, employers can make greater use of attrition and other alternatives to layoff. 
The use of short-time work in instances of structural adjustment is, however, more controversial. Economists typically take the position that in a permanent decline in demand, workers should be reallocated to other sectors as quickly as possible. To achieve this aim, large-scale layoffs, when necessary, have been advocated, on the assumption that dislocated workers will then be forced to find new employment. Several recent studies of displaced workers in the United States show, however, that workers permanently laid off from their jobs often experience long periods of unemployment. Among displaced workers aged 20 to 61 who lost full-time jobs between 1979 and 1981, for example, 31 percent of male blue-collar workers, 38 percent of female blue-collar workers, 14 percent of male white-collar workers, and 28 percent of female white-collar workers experienced more than a year of subsequent joblessness. ${ }^{22}$ Only 65 percent of prime-aged full-time workers displaced during 1984 held full-time jobs in January 1986; 8 percent held part-time jobs, 16 percent were unemployed, and 11 percent had withdrawn from the labor force. ${ }^{23}$

By using short-time work as an interim adjustment measure and relying on attrition to reduce the work force, firms can greatly reduce or even avoid layoffs. In this way, job reductions occur among those who have the most attractive outside opportunities or who are best able to relocate, and those who have poor outside opportunities or who are unable to relocate are not thrown out of work.

\section{INVENTORY ADJUSTMENT}

In the dynamic factor demand models estimated above, we allow only employment and average hours per worker to vary in the short run. The theoretical literature in economics, however, has long speculated that companies use finished goods inventories to buffer production and labor against short-run fluctuations in demand. Under the assumption that there are significant costs to adjusting labor and other factor inputs, firms might be expected to build up finished goods inventories during a downturn and to draw down inventory stocks during an upturn to mitigate costly changes in production and labor. If, in fact, the cost of adjusting labor input is greater in Germany than in the United States, we might expect that finished goods inventories would play a more important role in smoothing over demand fluctuations in Germany than in the United States.

To assess their role in the adjustment process in Germany and the Unired States, we expand the system of equations estimated above to incorporate inventories:

$$
\begin{aligned}
& \ln E_{t}=\alpha_{10}+\alpha_{11} \ln E_{t-1}+\alpha_{12} \ln h_{t-1}+\alpha_{13} \ln I_{t-1}+\beta_{1} \ln S_{t}+\phi_{11} t+\phi_{12} t^{2}+e_{1 t} \\
& \ln h_{t}=\alpha_{20}+\alpha_{21} \ln E_{t-1}+\alpha_{22} \ln h_{t-1}+\alpha_{23} \ln I_{t-1}+\beta_{2} \ln S_{t}+\phi_{21} t+\phi_{22} t^{2}+e_{2 t} \\
& \ln I_{t}=\alpha_{30}+\alpha_{31} \ln E_{t-1}+\alpha_{32} \ln h_{t-1}+\alpha_{33} \ln I_{t-1}+\beta_{3} \ln S_{t}+\phi_{31} t+\phi_{32} t^{2}+e_{3 t}
\end{aligned}
$$

where $I$ represents finished goods inventories and all other variables are defined as above. In this model an equation is added to estimate the short-run response of 
finished goods inventories to output changes. In addition, employment and hours adjustment are assumed to depend upon the path of adjustment of inventories. This model is quite similar to that estimated in Topel (1982). ${ }^{24}$

Several caveats should be noted concerning the data used to estimate these equations. Unfortunately, inventory data for Germany, which come from a special survey conducted by the IFO-Institut für Wirtschaftsforschung, are only available beginning in 1980 . Therefore, we estimate equations (2a), (2b), and (2c) over the 1980-1990 period, using seasonally adjusted, quarterly data, for both Germany and the United States. In addition, the IFO survey reports finished goods inventories in terms of the equivalent number of weeks of shipments, rather than in terms of the value of inventories. To convert the German weeks-of-inventory terms to stock values, we calculated the average weekly shipments over the preceding twelve months and multiplied this figure by the reported number of weeks of inventories.

Inventory data also are not reported for aggregate manufacturing in Germany. To construct an aggregate manufacturing series we summed the value of finished goods inventories across all of the more detailed industries for which inventory data were reported and for which we had shipments and labor market data. We aggregated shipments, employment, and hours data across the same set of industries to form a consistent series. This aggregate industry represents most of manufacturing. The primary industries excluded are food and tobacco.

Finished goods inventory data are not available for the U.S. auto industry and, because of changes in industry definitions, we do not have a complete series on inventories for the U.S. electrical equipment and instruments industries. In addition, because of missing post-1985 German shipments data, we do not report estimates of the expanded model for the paper industry. Data sources and additional details concerning the construction of the variables used in our analysis are given in the data appendix.

Paralleling the analysis reported above, we use the parameter estimates from equations (2a), (2b), and (2c) to simulate the response of production employment, production hours, and finished goods inventories to a one unit shock to shipments. The results of these simulations are summarized in Table 12.2. (We report selected coefficient estimates from the equations underlying these simulations in Table 12.4, which appears in the Appendix). The patterns of employment and hours adjustment shown in Table 12.2 are similar to those shown in Table 12.1. Short-run employment adjustment is typically larger in the United States than in Germany. Conversely, short-run average hours adjustment is usually larger in Germany than in the United States. In contrast to the estimates reported in Table 12.1 for the 1973-1990 period, the aggregate manufacturing equations for the 1980-1990 period do not imply a significant difference in the adjustment of total hours in the two countries. Consistent with the estimates for the 1973-1990 period, the 1980-1990 estimates for disaggregated industries generally imply that total hours adjustment is not significantly different in Germany and the United States. In sum, comparisons of employment and hours adjustment appear to be 
SUSAN N. HOUSEMAN, KATHARINE G. ABRAHAM

Table 12.2 Simulated Adjustment of Production Employment, Production Hours and Finished Goods Inventories to a Permanent One-Unit Shock to Shipments in German and U.S. Manufacturing Industries, 1980-90²

\begin{tabular}{|c|c|c|c|c|c|c|c|c|}
\hline \multirow[b]{2}{*}{ Industry/Lag } & \multicolumn{2}{|c|}{ Employment } & \multicolumn{2}{|c|}{ Average Hours } & \multicolumn{2}{|c|}{ Total Hours } & \multicolumn{2}{|c|}{ Inventories } \\
\hline & Germany & U.S. & Germany & U.S. & Germany & U.S. & Germany & U.S. \\
\hline \multicolumn{9}{|l|}{ Manufacturing } \\
\hline Current Quarter & $\begin{array}{c}0.16^{\circ} \\
(0.03)\end{array}$ & $\begin{array}{c}0.47 \\
(0.04)\end{array}$ & $\begin{array}{c}0.48^{\circ} \\
(0.06)\end{array}$ & $\begin{array}{c}0.21 \\
(0.03)\end{array}$ & $\begin{array}{c}0.63 \\
(0.07)\end{array}$ & $\begin{array}{c}0.68 \\
(0.05)\end{array}$ & $\begin{array}{c}-0.05 \\
(0.29)\end{array}$ & $\begin{array}{r}-0.26 \\
(0.23)\end{array}$ \\
\hline 1 Quarter & $\begin{array}{c}0.34^{\circ} \\
(0.05)\end{array}$ & $\begin{array}{c}0.74 \\
(0.05)\end{array}$ & $\begin{array}{c}0.42 \\
(0.08)\end{array}$ & $\begin{array}{c}0.25 \\
(0.04)\end{array}$ & $\begin{array}{c}0.76^{\circ} \\
(0.09)\end{array}$ & $\begin{array}{c}0.98 \\
(0.06)\end{array}$ & $\begin{array}{c}-0.06 \\
(0.45)\end{array}$ & $\begin{array}{r}-0.32 \\
(0.33)\end{array}$ \\
\hline 2 Quarters & $\begin{array}{c}0.50^{\circ} \\
(0.07)\end{array}$ & $\begin{array}{c}0.88 \\
(0.07)\end{array}$ & $\begin{array}{c}0.36 \\
(0.07)\end{array}$ & $\begin{array}{c}0.22 \\
(0.05)\end{array}$ & $\begin{array}{c}0.86 \\
(0.10)\end{array}$ & $\begin{array}{c}1.10 \\
(0.07)\end{array}$ & $\begin{array}{c}-0.08 \\
(0.58)\end{array}$ & $\begin{array}{c}-0.25 \\
(0.40)\end{array}$ \\
\hline 4 Quarters & $\begin{array}{c}0.72 \\
(0.10)\end{array}$ & $\begin{array}{c}0.96 \\
(0.10)\end{array}$ & $\begin{array}{c}0.28 \\
(0.08)\end{array}$ & $\begin{array}{c}0.13 \\
(0.07)\end{array}$ & $\begin{array}{c}1.00 \\
(0.11)\end{array}$ & $\begin{array}{c}1.09 \\
(0.11)\end{array}$ & $\begin{array}{c}-0.16 \\
(0.77)\end{array}$ & $\begin{array}{c}-0.01 \\
(0.55)\end{array}$ \\
\hline 6 Quarters & $\begin{array}{c}0.88 \\
(0.12)\end{array}$ & $\begin{array}{c}0.93 \\
(0.12)\end{array}$ & $\begin{array}{c}0.22 \\
(0.08)\end{array}$ & $\begin{array}{c}0.09 \\
(0.08)\end{array}$ & $\begin{array}{c}1.10 \\
(0.13)\end{array}$ & $\begin{array}{c}1.02 \\
(0.14)\end{array}$ & $\begin{array}{c}-0.24 \\
(0.95)\end{array}$ & $\begin{array}{c}0.26 \\
(0.73)\end{array}$ \\
\hline
\end{tabular}

Textiles

$\begin{array}{lcccccccc}\text { Current Quarter } & 0.14 & 0.25 & 0.63^{\circ} & 0.28 & 0.76 & 0.52 & -0.34 & -0.08 \\ & (0.03) & (0.05) & (0.08) & (0.06) & (0.09) & (0.09) & (0.30) & (0.09) \\ \text { 1 Quarter } & 0.37 & 0.39 & 0.56^{\circ} & 0.31 & 0.93 & 0.70 & -0.24 & -0.01 \\ & (0.05) & (0.06) & (0.10) & (0.06) & (0.12) & (0.08) & (0.50) & (0.16) \\ \text { 2 Quarters } & 0.57 & 0.47 & 0.52 & 0.27 & 1.09 & 0.74 & -0.19 & 0.09 \\ & (0.08) & (0.06) & (0.11) & (0.07) & (0.16) & (0.08) & (0.68) & (0.22) \\ \text { 4 Quarters } & 0.93^{\circ} & 0.53 & 0.45 & 0.17 & 1.37^{\circ} & 0.70 & -0.12 & 0.25 \\ & (0.15) & (0.09) & (0.18) & (0.10) & (0.26) & (0.11) & (0.97) & (0.32) \\ \text { 6 Quarters } & 1.22^{\circ} & 0.53 & 0.39 & 0.13 & 1.61^{\circ} & 0.66 & -0.08 & 0.33 \\ & (0.23) & (0.12) & (0.24) & (0.14) & (0.38) & (0.13) & (1.27) & (0.42)\end{array}$

\begin{tabular}{lcccccccc}
\hline Apparel & & & & & & & & \\
Current Quarter & 0.13 & 0.10 & $0.24^{\circ}$ & 0.06 & $0.36^{\circ}$ & 0.16 & 0.19 & 0.06 \\
& $(0.04)$ & $(0.05)$ & $(0.07)$ & $(0.05)$ & $(0.08)$ & $(0.06)$ & $(0.45)$ & $(0.18)$ \\
1 Quarter & 0.27 & 0.17 & 0.25 & 0.09 & 0.52 & 0.26 & 0.31 & 0.22 \\
& $(0.07)$ & $(0.07)$ & $(0.08)$ & $(0.08)$ & $(0.11)$ & $(0.11)$ & $(0.54)$ & $(0.30)$ \\
2 Quarters & 0.41 & 0.21 & 0.23 & 0.10 & 0.64 & 0.31 & 0.13 & 0.43 \\
& $(0.09)$ & $(0.10)$ & $(0.08)$ & $(0.09)$ & $(0.13)$ & $(0.14)$ & $(0.55)$ & $(0.39)$ \\
4 Quarters & $0.63^{\circ}$ & 0.22 & 0.18 & 0.08 & 0.80 & 0.31 & -0.35 & 0.79 \\
& $(0.14)$ & $(0.13)$ & $(0.08)$ & $(0.11)$ & $(0.17)$ & $(0.18)$ & $(0.54)$ & $(0.53)$ \\
6 Quarters & $0.77^{\circ}$ & 0.19 & 0.14 & 0.07 & $0.90^{\circ}$ & 0.26 & -0.74 & 0.93 \\
& $(0.18)$ & $(0.15)$ & $(0.08)$ & $(0.11)$ & $(0.20)$ & $(0.20)$ & $(0.57)$ & $(0.64)$ \\
\hline
\end{tabular}

\begin{tabular}{lcccccccc}
\hline Printing & & & & & & & & \\
Current Quarter & 0.15 & 0.08 & $0.72^{\circ}$ & 0.01 & $0.87^{*}$ & 0.10 & -1.14 & 0.74 \\
& $(0.06)$ & $(0.03)$ & $(0.12)$ & $(0.02)$ & $(0.14)$ & $(0.04)$ & $(3.13)$ & $(0.21)$ \\
1 Quarter & 0.26 & 0.12 & $0.55^{\circ}$ & 0.02 & $0.81^{*}$ & 0.14 & 4.68 & 0.93 \\
& $(0.13)$ & $(0.04)$ & $(0.15)$ & $(0.03)$ & $(0.19)$ & $(0.06)$ & $(5.16)$ & $(0.25)$ \\
2 Quarters & 0.34 & 0.15 & $0.52^{\circ}$ & 0.02 & $0.86^{\circ}$ & 0.16 & 6.18 & 0.99 \\
& $(0.19)$ & $(0.06)$ & $(0.14)$ & $(0.04)$ & $(0.21)$ & $(0.08)$ & $(5.77)$ & $(0.30)$
\end{tabular}


LABOR ADJUSTMENT UNDER DIFFERENT INSTITUTIONAL STRUCTURES

Table 12.2 (Continued)

\begin{tabular}{|c|c|c|c|c|c|c|c|c|}
\hline \multirow[b]{2}{*}{ Industry/Lag } & \multicolumn{2}{|c|}{ Employment } & \multicolumn{2}{|c|}{ Average Hours } & \multicolumn{2}{|c|}{ Total Hours } & \multicolumn{2}{|c|}{ Inventories } \\
\hline & Germany & U.S. & Germany & U.S. & Germany & U.S. & Germany & U.S. \\
\hline 4 Quarters & $\begin{array}{c}0.45 \\
(0.30)\end{array}$ & $\begin{array}{c}0.18 \\
(010)\end{array}$ & $\begin{array}{r}0.47^{\circ} \\
0\end{array}$ & $\begin{array}{c}0.01 \\
(0.04)\end{array}$ & $\begin{array}{c}0.92^{\circ} \\
(0.30)\end{array}$ & $\begin{array}{c}0.20 \\
(0.13)\end{array}$ & $\begin{array}{c}8.07 \\
(6.68)\end{array}$ & $\begin{array}{c}1.02 \\
(0.37)\end{array}$ \\
\hline 6Q Quarters & $\begin{array}{c}0.52 \\
(0.39)\end{array}$ & $\begin{array}{c}0.20 \\
(0.13)\end{array}$ & $\begin{array}{c}0.44^{\circ} \\
(0.20)\end{array}$ & $\begin{array}{c}0.01 \\
(0.05)\end{array}$ & $\begin{array}{c}0.97 \\
(0.39)\end{array}$ & $\begin{array}{c}0.21 \\
(0.16)\end{array}$ & $\begin{array}{c}9.00) \\
9.20 \\
(7.75)\end{array}$ & $\begin{array}{c}1.04 \\
(0.43)\end{array}$ \\
\hline \multicolumn{9}{|l|}{ Leather } \\
\hline Current Quarter & $\begin{array}{c}0.14 \\
(0.04)\end{array}$ & $\begin{array}{c}0.13 \\
(0.05)\end{array}$ & $\begin{array}{r}0.32^{\circ} \\
(0.07)\end{array}$ & $\begin{array}{c}0.04 \\
(0.04)\end{array}$ & $\begin{array}{c}0.46^{\circ} \\
(0.08)\end{array}$ & $\begin{array}{c}0.16 \\
(0.06)\end{array}$ & $\begin{array}{c}0.57 \\
(0.42)\end{array}$ & $\begin{array}{c}0.07 \\
(0.13)\end{array}$ \\
\hline 1 Quarter & $\begin{array}{c}0.28 \\
(0.07)\end{array}$ & $\begin{array}{c}0.19 \\
(0.08)\end{array}$ & $\begin{array}{c}0.30^{\circ} \\
(0.07)\end{array}$ & $\begin{array}{c}0.04 \\
(0.05)\end{array}$ & $\begin{array}{c}0.58^{\circ} \\
(0.09)\end{array}$ & $\begin{array}{c}0.23 \\
(0.09)\end{array}$ & $\begin{array}{c}0.76 \\
(0.65)\end{array}$ & $\begin{array}{c}0.11 \\
(0.19)\end{array}$ \\
\hline 2 Quarters & $\begin{array}{c}0.40 \\
(0.09)\end{array}$ & $\begin{array}{c}0.22 \\
(0.10)\end{array}$ & $\begin{array}{c}0.27^{\circ} \\
(0.08)\end{array}$ & $\begin{array}{c}0.03 \\
(0.07)\end{array}$ & $\begin{array}{c}0.67^{\circ} \\
(0.11)\end{array}$ & $\begin{array}{c}0.25 \\
(0.12)\end{array}$ & $\begin{array}{c}0.70 \\
(0.81)\end{array}$ & $\begin{array}{c}0.15 \\
(0.26)\end{array}$ \\
\hline 4 Quarters & $\begin{array}{c}0.56 \\
(0.13)\end{array}$ & $\begin{array}{c}0.24 \\
(0.17)\end{array}$ & $\begin{array}{c}0.18 \\
(0.09)\end{array}$ & $\begin{array}{c}0.01 \\
(0.10)\end{array}$ & $\begin{array}{r}0.74^{\circ} \\
(0.16)\end{array}$ & $\begin{array}{c}0.25 \\
(0.18)\end{array}$ & $\begin{array}{c}0.18 \\
(1.02)\end{array}$ & $\begin{array}{c}0.20 \\
(0.46)\end{array}$ \\
\hline 6Q Quarters & $\begin{array}{c}0.62 \\
(0.17)\end{array}$ & $\begin{array}{c}0.24 \\
(0.29)\end{array}$ & $\begin{array}{c}0.10 \\
(0.11)\end{array}$ & $\begin{array}{c}0.00 \\
(0.15)\end{array}$ & $\begin{array}{c}0.73 \\
(0.19)\end{array}$ & $\begin{array}{c}0.24 \\
(0.29)\end{array}$ & $\begin{array}{c}0.51 \\
(1.19)\end{array}$ & $\begin{array}{c}0.21 \\
(0.88)\end{array}$ \\
\hline
\end{tabular}

Stone, Clay, and Glass

$\begin{array}{lcccccccc}\text { Current Quarter } & 0.08^{*} & 0.20 & 0.26^{*} & 0.12 & 0.34 & 0.33 & -0.15 & -0.29 \\ & (0.03) & (0.04) & (0.04) & (0.02) & (0.05) & (0.05) & (0.26) & (0.09) \\ \text { 1 Quarter } & 0.12^{*} & 0.43 & 0.29^{\circ} & 0.17 & 0.42 & 0.60 & -0.21 & -0.42 \\ & (0.05) & (0.06) & (0.05) & (0.03) & (0.07) & (0.07) & (0.36) & (0.13) \\ \text { 2 Quarters } & 0.15^{\circ} & 0.60 & 0.30^{\circ} & 0.16 & 0.47^{\circ} & 0.76 & -0.17 & -0.45 \\ & (0.07) & (0.07) & (0.06) & (0.03) & (0.09) & (0.09) & (0.44) & (0.15) \\ \text { 4 Quarters } & 0.19^{\circ} & 0.70 & 0.31^{\circ} & 0.10 & 0.50 & 0.80 & -0.06 & -0.38 \\ & (0.11) & (0.08) & (0.07) & (0.04) & (0.14) & (0.09) & (0.55) & (0.19) \\ \text { 6 Quarters } & 0.22^{\circ} & 0.66 & 0.31^{\circ} & 0.07 & 0.53 & 0.73 & 0.01 & -0.34 \\ & (0.15) & (0.09) & (0.08) & (0.05) & (0.19) & (0.10) & (0.64) & (0.23)\end{array}$

Primary Metals

$\begin{array}{lllllllll}\text { Current Quarter } & 0.09^{*} & 0.38 & 0.37^{*} & 0.12 & 0.46 & 0.50 & -0.12 & 0.15\end{array}$

$\begin{array}{lcccccccc} & (0.02) & (0.06) & (0.06) & (0.02) & (0.07) & (0.06) & (0.29) & (0.08)\end{array}$

$\begin{array}{lcccccccc} & (0.05) & (0.07) & (0.06) & (0.03) & (0.08) & (0.07) & (0.33) & (0.13) \\ & 0.26^{\circ} & 0.59 & 0.28^{\circ} & 0.06 & 0.54 & 0.65 & -0.43^{\circ} & 0.56\end{array}$

$\begin{array}{lllllllll} & (0.07) & (0.09) & (0.05) & (0.04) & (0.09) & (0.08) & (0.41) & (0.21)\end{array}$

$\begin{array}{lllllllll}4 \text { Quarters } & 0.37 & 0.60 & 0.25^{\circ} & -0.01 & 0.62 & 0.60 & -0.46^{\circ} & 1.13\end{array}$

$\begin{array}{lcccccccc} & (0.14) & (0.15) & (0.06) & (0.06) & (0.15) & (0.13) & (0.56) & (0.44) \\ 6 \text { Quarters } & 0.44 & 0.61 & 0.23^{\circ} & -0.06 & 0.67 & 0.55 & -0.44^{\circ} & 1.75\end{array}$

$\begin{array}{llllllll}(0.24) & (0.22) & (0.07) & (0.11) & (0.24) & (0.19) & (0.71) & (0.81)\end{array}$

Nonelectrical Machinery

$\begin{array}{lllllllll}\text { Current Quarter } & 0.02^{\circ} & 0.53 & 0.10 & 0.16 & 0.12^{\circ} & 0.69 & 0.36^{\circ} & -0.35\end{array}$

$\begin{array}{llllllll}(0.02) & (0.10) & (0.05) & (0.03) & (0.05) & (0.10) & (0.19) & (0.29)\end{array}$ 
Table 12.2 (Continued)

\begin{tabular}{|c|c|c|c|c|c|c|c|c|}
\hline \multirow[b]{2}{*}{ Industry/ Lag } & \multicolumn{2}{|c|}{ Employment } & \multicolumn{2}{|c|}{ Average Hours } & \multicolumn{2}{|c|}{ Total Hours } & \multicolumn{2}{|c|}{ Inventories } \\
\hline & Germany & U.S. & Germany & U.S. & Germany & U.S. & Germany & U.S. \\
\hline 1 Quarter & $\begin{array}{c}0.04^{\circ} \\
(0.04)\end{array}$ & $\begin{array}{c}0.79 \\
(0.10)\end{array}$ & $\begin{array}{c}0.10 \\
(0.06)\end{array}$ & $\begin{array}{c}0.18 \\
(0.04)\end{array}$ & $\begin{array}{c}0.13^{\circ} \\
(0.07)\end{array}$ & $\begin{array}{c}0.97 \\
(0.09)\end{array}$ & $\begin{array}{c}0.49 \\
(0.35)\end{array}$ & $\begin{array}{r}-0.30 \\
(0.34)\end{array}$ \\
\hline 2 Quarters & $\begin{array}{c}0.05^{\circ} \\
(0.06)\end{array}$ & $\begin{array}{c}0.89 \\
(0.09)\end{array}$ & $\begin{array}{c}0.09 \\
(0.07)\end{array}$ & $\begin{array}{c}0.15 \\
(0.05)\end{array}$ & $\begin{array}{c}0.13^{4} \\
(0.09)\end{array}$ & $\begin{array}{c}1.04 \\
(0.08)\end{array}$ & $\begin{array}{c}0.61 \\
(0.51)\end{array}$ & $\begin{array}{r}-0.12 \\
(0.38)\end{array}$ \\
\hline 4 Quarters & $\begin{array}{c}0.05^{\circ} \\
(0.10)\end{array}$ & $\begin{array}{c}0.89 \\
(0.11)\end{array}$ & $\begin{array}{c}0.06 \\
(0.09)\end{array}$ & $\begin{array}{c}0.06 \\
(0.07)\end{array}$ & $\begin{array}{c}0.11^{\circ} \\
(0.14)\end{array}$ & $\begin{array}{c}0.96 \\
(0.09)\end{array}$ & $\begin{array}{c}0.85 \\
(0.81)\end{array}$ & $\begin{array}{r}0.26 \\
(0.51)\end{array}$ \\
\hline 6Quarters & $\begin{array}{c}0.03^{\circ} \\
(0.14)\end{array}$ & $\begin{array}{c}0.84 \\
(0.13)\end{array}$ & $\begin{array}{c}0.05 \\
(0.10)\end{array}$ & $\begin{array}{c}0.01 \\
(0.09)\end{array}$ & $\begin{array}{c}0.08 \\
(0.19)\end{array}$ & $\begin{array}{c}0.85 \\
(0.11)\end{array}$ & $\begin{array}{c}1.07 \\
(1.07)\end{array}$ & $\begin{array}{c}0.47 \\
(0.78)\end{array}$ \\
\hline \multicolumn{9}{|c|}{ Electrical Equipment } \\
\hline Current Quarter & $\begin{array}{c}0.07 \\
(0.05)\end{array}$ & NA & $\begin{array}{c}0.49 \\
(0.09)\end{array}$ & NA & $\begin{array}{c}0.57 \\
(0.09)\end{array}$ & NA & $\begin{array}{c}-0.12 \\
(0.50)\end{array}$ & NA \\
\hline 1 Quarter & $\begin{array}{c}0.16 \\
(0.10)\end{array}$ & - & $\begin{array}{c}0.46 \\
(0.12)\end{array}$ & - & $\begin{array}{c}0.62 \\
(0.13)\end{array}$ & 一 & $\begin{array}{c}-0.13 \\
(0.91)\end{array}$ & - \\
\hline 2 Quarters & $\begin{array}{c}0.23 \\
(0.18)\end{array}$ & - & $\begin{array}{c}0.43 \\
(0.12)\end{array}$ & - & $\begin{array}{c}0.66 \\
(0.17)\end{array}$ & - & $\begin{array}{c}-0.49 \\
(1.55)\end{array}$ & - \\
\hline 4 Quarters & $\begin{array}{c}0.33 \\
(0.46)\end{array}$ & - & $\begin{array}{c}0.38 \\
(0.17)\end{array}$ & 一 & $\begin{array}{c}0.71 \\
(0.37)\end{array}$ & 一 & $\begin{array}{c}-0.56 \\
(5.23)\end{array}$ & - \\
\hline 6 Quarters & $\begin{array}{c}0.39 \\
(1.15)\end{array}$ & - & $\begin{array}{c}0.35 \\
(0.31)\end{array}$ & - & $\begin{array}{c}0.74 \\
(0.91)\end{array}$ & - & $\begin{array}{c}-0.59 \\
(22.94)\end{array}$ & 一 \\
\hline \multicolumn{9}{|l|}{ Autos } \\
\hline Current Quarter & $\begin{array}{c}0.10 \\
(0.02)\end{array}$ & NA & $\begin{array}{c}0.61 \\
(0.11)\end{array}$ & NA & $\begin{array}{c}0.71 \\
(0.11)\end{array}$ & NA & $\begin{array}{c}-1.98 \\
(0.90)\end{array}$ & NA \\
\hline 1 Quarter & $\begin{array}{c}0.20 \\
(0.04)\end{array}$ & - & $\begin{array}{c}0.63 \\
(0.16)\end{array}$ & - & $\begin{array}{c}0.82 \\
(0.16)\end{array}$ & - & $\begin{array}{c}-3.59 \\
(1.58)\end{array}$ & 一 \\
\hline 2 Quarters & $\begin{array}{c}0.28 \\
(0.06)\end{array}$ & 一 & $\begin{array}{c}0.62 \\
(0.18)\end{array}$ & - & $\begin{array}{c}0.90 \\
(0.19)\end{array}$ & - & $\begin{array}{c}-4.82 \\
(2.09)\end{array}$ & - \\
\hline 4 Quarters & $\begin{array}{c}0.42 \\
(0.11)\end{array}$ & - & $\begin{array}{c}0.60 \\
(0.20)\end{array}$ & - & $\begin{array}{c}1.02 \\
(0.23)\end{array}$ & - & $\begin{array}{c}-6.53 \\
(2.79)\end{array}$ & - \\
\hline 6 Quarters & $\begin{array}{c}0.52 \\
(0.15)\end{array}$ & - & $\begin{array}{c}0.58 \\
(0.22)\end{array}$ & - & $\begin{array}{c}1.11 \\
(0.27)\end{array}$ & - & $\begin{array}{c}-7.66 \\
(3.29)\end{array}$ & - \\
\hline \multicolumn{9}{|l|}{ Instruments } \\
\hline Current Quarter & $\begin{array}{c}0.18 \\
(0.03)\end{array}$ & NA & $\begin{array}{c}0.17 \\
(0.06)\end{array}$ & NA & $\begin{array}{c}0.35 \\
(0.07)\end{array}$ & NA & $\begin{array}{c}-1.21 \\
(0.35)\end{array}$ & NA \\
\hline 1 Quarter & $\begin{array}{c}0.37 \\
(0.04)\end{array}$ & - & $\begin{array}{c}0.14 \\
(0.04)\end{array}$ & - & $\begin{array}{c}0.51 \\
(0.07)\end{array}$ & - & $\begin{array}{c}-1.30 \\
(0.34)\end{array}$ & - \\
\hline 2 Quarters & $\begin{array}{c}0.51 \\
(0.05)\end{array}$ & - & $\begin{array}{c}0.08 \\
(0.04)\end{array}$ & - & $\begin{array}{c}0.58 \\
(0.07)\end{array}$ & - & $\begin{array}{c}-1.04 \\
(0.34)\end{array}$ & - \\
\hline 4 Quarters & $\begin{array}{c}0.65 \\
(0.06)\end{array}$ & - & $\begin{array}{c}-0.01 \\
(0.04)\end{array}$ & - & $\begin{array}{c}0.64 \\
(0.07)\end{array}$ & - & $\begin{array}{c}-0.56 \\
(0.36)\end{array}$ & - \\
\hline 6 Quarters & $\begin{array}{c}0.70 \\
(0.06)\end{array}$ & - & $\begin{array}{c}-0.04 \\
(0.04)\end{array}$ & - & $\begin{array}{c}0.66 \\
(0.07)\end{array}$ & - & $\begin{array}{c}-0.34 \\
(0.40)\end{array}$ & - \\
\hline
\end{tabular}

Notes:

- Standard errors are in parentheses.

- An asterisk denotes that the German-U.S. difference is significant at 0.05 level, two-tailed test. 
sensitive neither to the period of estimation nor to the inclusion of inventories in the model..$^{25}$

If inventories serve as a buffer stock, one would expect inventories to fall when shipments rise and to rise when shipments fall. In Table 12.2, which shows the response of inventories to a permanent one unit, positive shock to shipments, one would expect initial inventory adjustment to be negative. For aggregate manufacturing, inventory adjustment is negative for most time horizons in both Germany and the United States, but is never significantly different from zero in either country. For the disaggregated industries reported in Table 12.2, inventory adjustment also tends to be very imprecisely estimated in both countries. Even where initial inventory adjustment has the expected negative sign, it generally is not significantly different from zero.

There are, however, several exceptions. For the auto and instruments industries in Germany and for the stone, clay, and glass industry in the United States, inventory adjustment to a change in shipments is large and statistically significant across all or most time horizons. For example, the simulations suggest that a 1 percent increase in shipments would result in a 1.98 percent decrease in inventories in the contemporaneous quarter in the German auto industry; a 1.21 percent decrease in inventories in the contemporaneous quarter in the German instruments industry; and a 0.29 percent decrease in inventories in the contemporaneous quarter in the U.S. stone, clay, and glass industry. These rather large inventories elasticities are noteworthy, of course, only if inventories represent a sizable fraction of shipments in these industries. Based on a separate set of simulations in which the shock to shipments was evaluated at the mean of the industry's shipments, only an estimated 6 percent share of an increase in shipments in the German auto industry would be absoibed by lower inventory stocks in the quarter contemporaneous to the shock to shipments. In the German instruments industry and in the U.S. stone, clay, and glass industry inventories appear to play a more important role in buffering production. In the German instruments industry, an increase in shipments is estimated to be more than matched by a fall in inventories in the contemporaneous quarter and in the U.S. stone, clay, and glass industry 19 percent of an increase in shipments would be absorbed by a decrease in inventories in the contemporaneous quarter.

These exceptions aside, the main conclusion to be drawn from Table 12.2 is that inventories do not appear to play a significant role in smoothing over fluctuations in demand in either Germany or the United States. The results concerning U.S. inventory adjustment presented in Table 12.2 are consistent with other research, which has found little evidence of a buffer role for finished goods inventories in the United States. ${ }^{26}$ Even in estimates of the interrelated factor demand model that includes inventories run over the 1973-1990 period (not reported here) we find no evidence to suggest that inventories play a substantial role in smoothing over fluctuations in demand in the United States.

Ideally, we would like to have estimated these inventory adjustment equations over a longer time horizon for Germany. German manufacturing 
experienced little cyclical fluctuation during the 1980's, and it is possible that the imprecise estimates we obtain are partly due to the lack of variation in the data. Still, our basic finding that inventories do not appear to play a significant buffer role in Germany is consistent with our findings concerning employment and hours adjustment. We hypothesized that if the costs of labor adjustment were higher in Germany than in the United States so that German firms adjusted labor input more slowly to demand changes than did U.S. firms, German firms would have a greater incentive to use inventories to buffer fluctuations in demand. However, we find that, although German firms adjust employment more slowly than do U.S. firms, there is little difference in the adjustment of total labor input.

\section{CONCLUSION}

Concerns about the potential impacts of job security legislation often are based upon the perception that such legislation slows or prevents needed labor market adjustment. Taken as a whole, our results suggest that the primary difference between German and U.S. labor adjustment lies not in the adjustment of total labor input, but rather in its division between adjustments to the number of workers employed and adjustments to hours per worker. German companies rely much more on the adjustment of average hours, including the use of short-time work, to reduce labor input during downturns; American companies make greater use of employment adjustment, and by implication layoffs. At least in the German manufacturing sector, adjustment of hours per worker serves as a short-run substitute for the adjustment of employment levels.

Likcly reasons for the very different composition of labor adjustmerits in the two countries are easy to identify. German job security laws and prevailing German practice discourage the adjustment of employment to changes in the demand for labor that may not prove to be permanent and make rapid employment adjustment difficult, while the German unemployment insurance system encourages reductions in hours during periods of slack demand and the relatively low overtime premium may encourage adjustment of overtime hours. In the United States, in contrast, there are no legal barriers to layoffs, the unemployment insurance system offers positive incentives to lay workers off rather than reduce their weekly hours, and the relatively high mandatory overtime premium may discourage adjustment through variation in overtime hours. Our results suggest that the higher costs of adjusting employment levels in Germany are offset, in most cases, by lower costs of adjusting average hours, so that the adjustment of total labor input in the two countries is similar. Our findings concerning the adjustment of inventories in response to demand changes support this conclusion, albeit indirectly. If the costs of adjusting labor input were significantly greater in Germany, we might expect that employers would use stocks of finished goods inventories to buffer fluctuations in demand to a greater degree than in the United States. In fact, we find little evidence to suggest that inventories are used for this purpose in either country. 
Taken as a whole, the evidence reported in this chapter casts doubt on allegations that dismissal legislation in West Germany has seriously hampered German firms' ability to adjust their labor input in response to changing demand conditions. Our findings suggest that, given the presence of appropriate supporting institutions, strong worker job security can be compatible with employers' need for flexibility in staffing levels.

\section{ACKNOWLEDGMENTS}

We have benefited from comments on an earlier draft of this paper made by participants at a workshop on "Institutional Frameworks and Labor Market Performance" at the Wissenschaftszentrum für Sozialforschung in Berlin, December 1992. We are grateful to Carolyn Thies for providing outstanding research assistance and to Claire Vogelsong for secretarial support.

\section{NOTES}

1 For summaries of recent changes to employment protection laws in Western Europe, see Maury (1985), Vranken (1986), and Houseman (1990).

2 For an elaboration of these arguments, see OECD (1986) and Soltwedel (1988).

3 Wall Street Journal, October 12, 1993.

4 Required notice periods can be circumvented through voluntary severance agreements under which workers quit in return for some monetary compensation. Such agreements have been common. A 1990 decision of the Federal Constitutional Court declared the disparate treatment of blue-collar and white-collar workers in advance notice law to be unconstitutional and ordered parliament to pass new legislation providing for equal notice.

5 German dismissal law and the role of the works council in the event of a collective dismissal are discussed by Bruche and Reissert (1984), Sengenberger (1985), and Weiss (1985).

6 The German short-time system is discussed by Flechsenhar (1980) and Grais (1983).

7 See General Accounting Office (1986) for survey results on the incidence of advance notice and severance pay.

8 At least 50 workers must be affected, and therefore small establishments are exempted from any notice requirement. The requirements of advance notice also apply if 500 or more workers are laid off, even if they do not constitute at least one third of the work force.

9 Unemployment Insurance Financial Data, published by the U.S. Department of Labor, contains data on weekly benefit amounts, weekly wages in covered employment, and the duration of benefit receipt. Vroman (1989) discusses alternative estimates of the degree of experience rating.

10 Formal models of the effects of employment adjustment costs on both employment and hours are surveyed by Nickell (1986) and Hamermesh (1993). Burdett and Wright (1989) model the effect of access to short-time compensation through the UI system. In their model, the short-time compensation subsidy associated with imperfect experience rating increases employers' reliance on hours adjustments and raises the volatility of average hours relative to the volatility of employment. Even in a perfectly experience rated UI system, giving liquidity-constrained employers access to short-time benefits for their workers may produce the same result. Hamermesh (1993) discusses the effects of overtime premia on the choice between hours and employment adjustments. 
11 The model we use here to estimate employment and hours adjustment differs from those employed in our earlier work. In Abraham and Houseman (1993) we use a finite distributed lag model to describe the response of employment and total hours to changes in shipments. In Abraham and Houseman (1994) we use Koyck models to estimate separately the adjustment of employment and the adjustment of total hours to demand changes. Neither model allowed the adjustment of employment and average hours to be interrelated. In addition, neither model allowed for the direct comparison of employment and average hours adjustment.

12 We also estimate models with data that had not been seasonally adjusted. In general, the results are quite similar to those reported in this chapter.

13 The automobile industry is the only industry included for which the German and U.S. definitions are not wholly comparable; the German classification includes bicycles, whereas the U.S. classification does not.

14 We estimate standard errors associated with the simulated adjustment paths using "bootstrap" methods. Specifically, we use Monte Carlo simulation techniques to perturb randomly the estimated coefficients in equations ( $1 \mathrm{a})$ and (lb), and generate new simulated paths of adjustment for employment and hours. The reported standard errors are calculated as the standard deviation of the values at the associated lag lengths of 100 Monte Carlo simulations.

15 As noted above, the German street vehicles industry includes bicycles whereas the U.S. auto industry does not.

16 Houseman (1988) did report slower total hours adjustment in the German than in the U.S. steel industry using a finite distributed lag model. In Abraham and Houseman (1993), in which we used a model similar to that in Houseman (1988), we found that once differences in demand conditions were taken into account, differences in total hours adjustment in the German and U.S. primary metals industry largely disappeared.

17 These results are available upon request.

18 Figure 2 in Katz and Meyer (1990) indicates that the aggregate new job hazard, a measure of the instantaneous probability that an unemployed person will take a new job, is about 0.025 , while the results in their Table 6 suggest that, all else the same, the new job hazard is roughly 40 percent lower for persolis who initially expect to be recalled to their previous job. Given that about 75 percent of their sample begins their layoff spell expecting to be recalled, a reasonable estimate of the new job hazard for this group is about 0.021 . This is the hazard assumed in arriving at the numbers in the text.

19 There also would be some voluntary attrition during an extended period of short-time work, but quit rates are typically far below the loss rates from temporary layoff status implied by Katz and Meyer's figures.

20 Katz and Meyer (1990: 981).

21 Figure 2 in Katz and Meyer (1990) indicates that the aggregate recall hazard, a measure of the instantaneous probability that an unemployed person will be recalled to the previous job, averages about 0.050 during the first 15 weeks following a layoff, then drops to about 0.010 . The results in their Table 6 suggest that the recall hazard is about 10 times greater for persons who initially expect to be recalled than for persons who do not. A reasonable estimate of the recall hazard for persons who begin their spell expecting to be recalled is 0.065 during the first fifteen weeks of a layoff spell and about 0.013 thereafter. These are the hazards used to compute the numbers in the text.

22 Podgursky and Swaim (1987: 216).

23 Seitchik and Zornitsky (1989: 67).

24 One key difference between our approach and that in Topel (1982) is in the modeling of demand. Topel attempts to distinguish between anticipated and unanticipated demand shocks. While this issue is of theoretical interest, whether one can disentangle anticipated from unanticipated demand shocks econometrically is highly questionable. 


\section{LABOR ADJUSTMENT UNDER DIFFERENT INSTITUTIONAL STRUCTURES}

25 We also have estimated equations (1a) and (1b) over the 1980-1990 period for Germany and the United States. Estimated employment and hours adjustment is very similar to that in the model including inventories fit for the same time period.

26 See Blinder and Maccini (1991) for a review of this literature.

\section{REFERENCES}

Abraham, K. G. and Houseman, S. N. (1993) Job Security in America: Lessons from Germany, Washington: Brookings Institution.

(1994) "Does Employment Protection Inhibit Labor Market Flexibility? Lessons from Germany, France and Belgium," in R. Blank (ed.) Social Protection Versus Economic Flexibility: Is There a Tradeoff?, Chicago: Chicago University Press.

Blinder, A. S. and Maccini, L. J. (1991) "Taking Stock: A Critical Assessment of Recent Research on Inventories," The Journal of Economic Perspectives 5, 1: 73-98.

Bruche, G. and Reissert, B. (1984) "Manpower and Regional Adjustment Policies: The Case of West Germany," mimeo, November.

Burdett, K. and Wright, R. (1989) "Unemployment Insurance and Short-Time Compensation: The Effects on Layoffs, Hours per Worker and Wages," Journal of Political Economy 97, 6: 1479-1496.

Flechsenhar, H. R. (1980) Kurzarbeit als Massnahme der betriebliche Anpassung, Frankfurt: Harri.

General Accounting Office (1986) "Dislocated Workers: Extent of Business Closures, Layoffs and the Public and Private Response," Briefing Report to the Honorable Lloyd Bentsen, United States Senate, July 1, 1986.

- (1993) "Dislocated Workers: Implementation of the Worker Adjustment and Retraining Notification Act (WARN)," testimony by Linda G. Morra before the Subcommittee on Labor and Human Resources of the U.S. Senate, February 23, 1993.

Grais, B. (1983) Layoffs and Short-time Working in Selected OECD Countries, Paris: OECD.

Hamermesh, D. (1993) Labor Demand, Princeton, NJ: Princeton University Press.

Hemmer, E. (1988) Sozialpraxis is der Bundesrepublik: Eine Empirische Untersuchung, Cologne: Deutscher Instituts-Verlag.

Houseman, S. N. (1988) "Shorter Working Time and Job Security: Labor Adjustment in the European Steel Industry," in R. Hart (ed.), Employment, Unemployment and Hours of Work, London: Unwin.

- (1990) "The Equity and Efficiency of Job Security: Contrasting Perspectives on Collective Dismissal Laws in Western Europe," in K. G. Abraham and R. B. McKersie (eds), New Developments in the Labor Market, Cambridge, MA: MIT Press.

Katz, L. F. and Meyer, B. D. (1990) "Unemployment Insurance, Recall Expectations, and Unemployment Outcomes," Quarterly Journal of Economics 105 (November): 973-1002.

Kohler, C. and Sengenberger, W. (1983) Konjunctur und Betriebliche Beschaeftingungspolitik in der deutschen und amerikanischen Automobilindustrie, Frankfurt: Campus.

Kraft, K. (1990) "Adjustment of Employment," mimeo, July.

Maury, J.-M. (1985) Labour Market Flexibility in the Member States of the Community, Paris: Centre for Research and Information on Technology, Economics and the Regions.

Nickell, S. J. (1986) "Dynamic Models of Labour Demand," in O. Ashenfelter and R. Layard (eds), Handbook of Labor Economics, Volume I, Amsterdam: Elsevier.

Organization for Economic Cooperation and Development (1986) Flexibility in the Labor Market: The Current Debate, Paris.

Podgursky, M. J. and Swaim, P. (1989) "Duration of Joblessness following Job Displacement," Industrial Relations 26 (Fall): 213-226.

Seitchik, A. and Zornitsky, J. (1989) From One Job to the Next: Worker Adjustment in a Changing Labor Market, Kalamazoo, MI: W.E. Upjohn Institute for Employment Research. 
Sengenberger, W. (1985) “Employment Security: Redundancy Arrangements and Practices in West Germany," report prepared for the OECD, Paris.

Soltwedel, R. (1988) "Employment Problems in West Germany: The Role of Institutions, Labor Law, and Government Intervention," Carnegie-Rochester Conference Series on Public Policy, 28: 153-220.

Topel, R. H. (1982) "Inventories, Layoffs and the Short-run Demand for Labor," American Economic Review 72, 4 (September): 769-787.

U.S. Department of Labor, Employment, and Training Administration (various years) Unemployment Insurance Financial Data, Washington: Government Printing Office.

Vranken, M. (1986) "Deregulating the Employment Relationship: Current Trends in Europe," Comparative Labor Law 7 (Winter): 143-165.

Vroman, W. (1989) "Experience Rating in Unemployment Insurance: Some Current Issues," U.S. Department of Labor, Employment and Training Administration, Unemployment Insurance Occasional Paper No. 89-6.

Weiss, M. (1985) "The Law and Practice of Restructuring Labour in the Enterprise," mimeo, August.

\section{APPENDIX}

The German production employment, hours and shipments data come from a monthly employer survey conducted by the Statistisches Bundesamt. These data are published monthly in Fachserie 4: Produzierendes Gewerbe, Reihe 4.1.1: Beschaeftigung, Umsatz und Energieversorgung der Unternehmen und Betriebe im Bergbau und im Verarbeitenden Gewerbe, issued by the Statistisches Bundesamt. Complete post-1985 shipments data were not available for the German paper industry. For that reason, we have not estimated models for the 1980-1990 period for paper. The German shipments data were deflated by a producer price index for basic industries, capital goods, consumer goods or food and tobacco, as appropriate. Because of a break in the German industry series, we do not use data prior to 1970. German finished goods inventory data come from a survey by IFO-Institute für Wirtschaftsforschung. This survey is conducted four times a year during the months of February, May, August, and November.

U.S. employment and hours data come from the Bureau of Labor Statistics' monthly Employment, Payroll, and Hours survey, as published monthly in Employment and Earnings. U.S. shipments and finished goods inventory data were obtained from the Bureau of the Census's Manufacturers' Shipments, Inventories, and Orders data set; these data are published in Current Industrial Reports: Manufacturers' Shipments, Inventories, and Orders, which appears annually. Finished goods inventory data are not available for the U.S. auto industry. In addition, as explained below, complete inventory series were not available for all industries on a consistent basis. The U.S. shipments and inventory data were deflated using either the durable goods or the nondurable goods producer price index.

With the exception of the producer price deflators, all series used in the analysis were obtained on magnetic media in unadjusted form and seasonally adjusted using the X-11 procedure in SAS. Because production employment was measured at the end of the month in Germany, but at mid-month in the United States, we transformed the German production employment numbers, defining:

$$
E_{t}^{\prime}=\frac{\left(E_{t}+E_{t-1}\right)}{2}
$$

These transformed numbers were used in all analyses.

The industries included in our analysis were matched using a bridge between the German 


\section{LABOR ADJUSTMENT UNDER DIFFERENT INSTITUTIONAL STRUCTURES}

SYPRO industry codes and the 1972 U.S. SIC industry codes developed by Hideki Yamawaki. Except for the automobile industry, all correspond to 2-digit SIC classifications. The U.S. SIC system was revised in 1987. All of the U.S. employment and hours adjustment equations summarized in Table 12.1 were estimated using data on a 1972 SIC basis. The 1987 SIC revisions resulted in major changes in the composition of SIC 36, electrical equipment, and SIC 38, instruments. We were unable to obtain recent finished goods inventory data on a 1972 basis and pre-1988 employment and hours data for these industries are not available on a 1987 basis. Therefore they are excluded from our analysis of employment, hours and inventories adjustment. The 1987 revisions also affected the composition of SIC 32, stone, clay and glass, and SIC 35, nonelectrical machinery, though in a much less significant way. For these industries we estimate the employment, hours, and inventories models summarized in Table 12.2 using data on a 1987 SIC basis.

All of the U.S. series are constructed using a "link relative" approach, meaning that the percentage change in the series value between period $t$ and period $t-1$ is first calculated using data from those establishments filing returns in both periods, and the period $t$ value then determined by applying this percentage change to the period $t-1$ value. The German series are not constructed in this way. Whether for this or some other reason, the German shipments series were considerably noisier than the corresponding U.S. series even after they had been seasonally adjusted. For that reason and because German inventory data are only available on a quarterly basis, we averaged the monthly data for both countries to construct quarterly observations, which have been used in the reported analysis. Again, however, making this adjustment had no important effect on any of our findings.

Neither country's data series are adjusted for the effect of strikes. We have added strike dummies to our estimating equations for the German automobile, primary metals, and printing industries in those quarters affected by large strikes. This has the effect of slightly reducing the estimated adjustment of hours worked to changes in output.

The data used in the preparation of Figure 12.2 make use of monthly data on the number of manufacturing workers collecting shorn-time payments. These numbers were taken from Amtliche Nachrichten der Bundesanstalt für Arbeit-Jahreszahlen (various issues). 
Table 12.3 Production Employment and Hours Adjustment: Selected Coefficient Estimates from an Interrelated Factor Demand Model

\begin{tabular}{lcccccc}
\hline Germany & $\alpha_{\| \prime}$ & $\alpha_{12}$ & $\beta_{I}$ & $\alpha_{2 l}$ & $\alpha_{22}$ & $\beta_{2}$ \\
\hline Manufacturing & 0.831 & 0.075 & 0.172 & -0.443 & 0.158 & 0.396 \\
& $(0.030)$ & $(0.029)$ & $(0.026)$ & $(0.060)$ & $(0.084)$ & $(0.050)$ \\
Textiles & 0.884 & 0.058 & 0.143 & -0.269 & 0.372 & 0.256 \\
& $(0.032)$ & $(0.038)$ & $(0.023)$ & $(0.052)$ & $(0.089)$ & $(0.048)$ \\
Apparel & 0.868 & 0.166 & 0.173 & -0.278 & 0.343 & 0.149 \\
& $(0.027)$ & $(0.048)$ & $(0.023)$ & $(0.056)$ & $(0.100)$ & $(0.049)$ \\
Paper & 0.912 & 0.154 & 0.033 & -0.176 & 0.128 & 0.299 \\
& $(0.062)$ & $(0.068)$ & $(0.035)$ & $(0.157)$ & $(0.188)$ & $(0.062)$ \\
Printing & 0.817 & 0.086 & 0.202 & -0.306 & 0.056 & 0.160 \\
& $(0.032)$ & $(0.053)$ & $(0.024)$ & $(0.055)$ & $(0.107)$ & $(0.041)$ \\
Leather & 0.776 & 0.067 & 0.192 & -0.413 & 0.296 & 0.276 \\
& $(0.034)$ & $(0.048)$ & $(0.031)$ & $(0.064)$ & $(0.090)$ & $(0.058)$ \\
Stone, Clay, and Glass & 0.870 & 0.001 & 0.120 & -0.180 & 0.312 & 0.185 \\
& $(0.024)$ & $(0.049)$ & $(0.015)$ & $(0.042)$ & $(0.085)$ & $(0.025)$ \\
Primary Metals & 0.806 & 0.035 & 0.080 & -0.395 & -0.139 & 0.432 \\
& $(0.064)$ & $(0.031)$ & $(0.016)$ & $(0.163)$ & $(0.082)$ & $(0.043)$ \\
Nonelectrical Machinery & 0.839 & 0.037 & 0.014 & -0.218 & 0.489 & 0.125 \\
& $(0.183)$ & $(0.043)$ & $(0.014)$ & $(0.061)$ & $(0.097)$ & $(0.040)$ \\
Electrical Equipment & 0.767 & 0.094 & 0.128 & -0.485 & 0.265 & 0.517 \\
& $(0.120)$ & $(0.039)$ & $(0.036)$ & $(0.056)$ & $(0.073)$ & $(0.059)$ \\
Autos & 0.883 & 0.103 & 0.127 & -0.402 & -0.040 & 0.482 \\
& $(0.020)$ & $(0.023)$ & $(0.014)$ & $(0.117)$ & $(0.097)$ & $(0.061)$ \\
Instruments & 0.785 & 0.194 & 0.131 & -0.242 & 0.362 & 0.126 \\
& $(0.063)$ & $(0.061)$ & $(0.029)$ & $(0.057)$ & $(0.101)$ & $(0.033)$
\end{tabular}

United States

\begin{tabular}{lcccccc}
\hline Manufacturing & 0.493 & 0.241 & 0.536 & -0.182 & 0.629 & 0.216 \\
& $(0.040)$ & $(0.106)$ & $(0.037)$ & $(0.021)$ & $(0.068)$ & $(0.028)$ \\
Textiles & 0.297 & 0.185 & 0.265 & -0.211 & 0.289 & 0.226 \\
& $(0.116)$ & $(0.109)$ & $(0.055)$ & $(0.081)$ & $(0.221)$ & $(0.063)$ \\
Apparel & 0.605 & 0.085 & 0.127 & -0.110 & 0.567 & 0.061 \\
& $(0.156)$ & $(0.145)$ & $(0.041)$ & $(0.041)$ & $(0.107)$ & $(0.018)$ \\
Paper & 0.344 & 0.648 & 0.245 & -0.132 & 0.635 & 0.063 \\
& $(0.096)$ & $(0.174)$ & $(0.055)$ & $(0.043)$ & $(0.206)$ & $(0.030)$ \\
Printing & 0.861 & 0.348 & 0.059 & -0.049 & 0.596 & 0.039 \\
& $(0.033)$ & $(0.173)$ & $(0.017)$ & $(0.020)$ & $(0.184)$ & $(0.014)$ \\
Leather & 0.600 & 0.086 & 0.212 & -0.152 & 0.521 & 0.094 \\
& $(0.132)$ & $(0.159)$ & $(0.041)$ & $(0.030)$ & $(0.093)$ & $(0.027)$ \\
Stone, Clay, and Glass & 0.631 & 0.165 & 0.315 & -0.127 & 0.627 & 0.129 \\
& $(0.052)$ & $(0.171)$ & $(0.042)$ & $(0.016)$ & $(0.065)$ & $(0.016)$ \\
Primary Metals & 0.380 & 0.113 & 0.372 & -0.215 & 0.512 & 0.150 \\
& $(0.062)$ & $(0.173)$ & $(0.032)$ & $(0.022)$ & $(0.072)$ & $(0.013)$ \\
Nonelectrical Machinery & 0.545 & 0.286 & 0.515 & -0.148 & 0.749 & 0.164 \\
& $(0.053)$ & $(0.182)$ & $(0.071)$ & $(0.020)$ & $(0.068)$ & $(0.030)$ \\
Electrical Equipment & 0.573 & 0.615 & 0.374 & -0.080 & 0.719 & 0.070 \\
& $(0.076)$ & $(0.228)$ & $(0.059)$ & $(0.017)$ & $(0.085)$ & $(0.021)$ \\
Autos & 0.397 & -0.004 & 0.433 & -0.186 & 0.416 & 0.189 \\
& $(0.056)$ & $(0.126)$ & $(0.032)$ & $(0.021)$ & $(0.080)$ & $(0.020)$ \\
Instruments & 0.720 & 0.452 & 0.195 & -0.062 & 0.695 & 0.108 \\
& $(0.129)$ & $(0.201)$ & $(0.057)$ & $(0.014)$ & $(0.084)$ & $(0.034)$ \\
& & & & & &
\end{tabular}




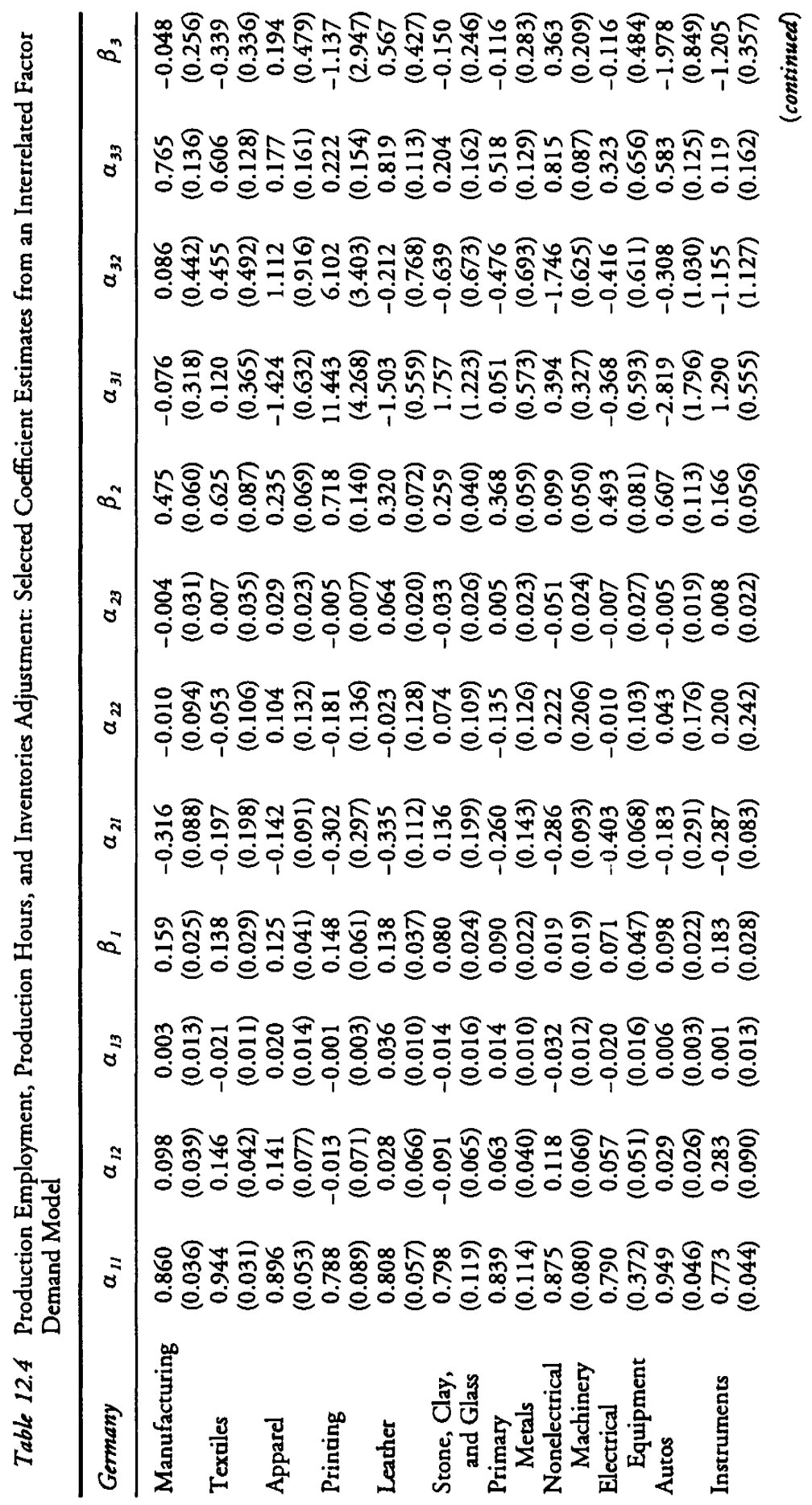




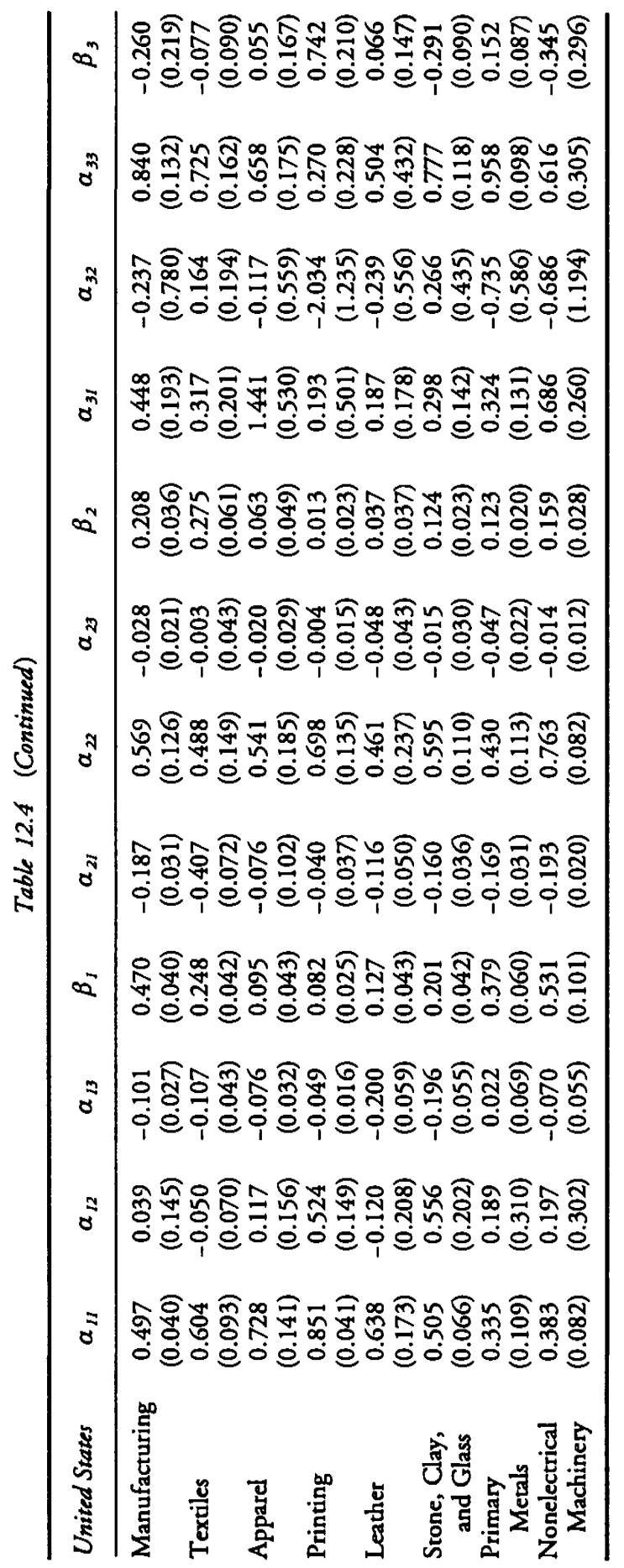

